\title{
Dual Specificity Phosphatase 1 Regulates Human Inducible Nitric Oxide Synthase Expression by p38 MAP Kinase
}

\author{
Tuija Turpeinen, ${ }^{1}$ Riina Nieminen, ${ }^{1}$ Ville Taimi, ${ }^{1}$ Taina Heittola, ${ }^{1}$ Outi Sareila, ${ }^{1}$ \\ Andrew R. Clark, ${ }^{2}$ Eeva Moilanen, ${ }^{1}$ and Riku Korhonen ${ }^{1}$ \\ ${ }^{1}$ The Immunopharmacology Research Group, University of Tampere School of Medicine and Tampere University Hospital, \\ Medisiinarinkatu 3, 33014 Tampere, Finland \\ ${ }^{2}$ The Kennedy Institute of Rheumatology, Imperial College London, London W6 8LH, UK
}

Correspondence should be addressed to Riku Korhonen, riku.korhonen@uta.fi

Received 17 December 2010; Accepted 15 February 2011

Academic Editor: Fulvio D’Acquisto

Copyright (C) 2011 Tuija Turpeinen et al. This is an open access article distributed under the Creative Commons Attribution License, which permits unrestricted use, distribution, and reproduction in any medium, provided the original work is properly cited.

The role of dual specificity phosphatase 1 (DUSP1) in inducible nitric oxide synthase (iNOS) expression in A549 human pulmonary epithelial cells, J774 mouse macrophages and primary mouse bone marrow-derived macrophages (BMMs) was investigated. iNOS expression was induced by a cytokine mixture (TNF, IFN $\gamma$ and IL-1 $\beta$ ) in A549 cells and by LPS in J774 cells, and it was inhibited by p38 MAPK inhibitors SB202190 and BIRB 796. Stimulation with cytokine mixture or LPS enhanced also DUSP1 expression. Down-regulation of DUSP1 by siRNA increased p38 MAPK phosphorylation and iNOS expression in A549 and 7774 cells. In addition, LPS-induced iNOS expression was enhanced in BMMs from DUSP1 $1^{(-/)}$mice as compared to that in BMMs from wild-type mice. The results indicate that DUSP1 suppresses iNOS expression by limiting p38 MAPK activity in human and mouse cells. Compounds that enhance DUSP1 expression or modulate its function may be beneficial in diseases complicated with increased iNOS-mediated NO production.

\section{Introduction}

Nitric oxide (NO) is a gaseous signaling molecule that regulates various physiological and pathophysiological processes in many tissues and organ systems. NO is synthesized from $\mathrm{L}$-arginine in a reaction catalyzed by nitric oxide synthase (NOS) enzyme. Three NOS enzyme isoforms exist: neuronal NOS (nNOS), inducible NOS (iNOS), and endothelial NOS (eNOS). nNOS and eNOS are constitutively expressed, and, in general, they produce relatively small amounts of $\mathrm{NO}$ in the context of physiological regulation of cellular and tissue functions. The expression of iNOS is induced by a number inflammatory and other stimuli, such as inflammatory cytokines, bacterial products, and hypoxia. NO is an important effector molecule in microbicidal host defense, and it serves as a regulatory and proinflammatory molecule in acute and chronic inflammatory responses [1-4].

The expression of iNOS is regulated at transcriptional and posttranscriptional levels. There are considerable differe- nces in the transcriptional regulation of mouse and human iNOS expression. Mouse iNOS promoter activity is substantially induced by interferon (IFN) $\gamma$ and bacteria-derived substances, such as lipopolysaccharide (LPS). iNOS promoter contains two regions responsive to LPS and IFNs. The proximal region is located between -48 and $-209 \mathrm{bp}$ upstream of transcriptional start site and contains binding site for nuclear factor $\kappa \mathrm{B}(\mathrm{NK}-\kappa \mathrm{B})$ and is essential for NF- $\kappa$ B-dependent inducible iNOS promoter activity. The distal region, at position -913 to $-1029 \mathrm{bp}$, contains NF$\mathrm{kB}$ binding site, gamma-activated site (GAS) and two copies of interferon-stimulated response element (ISRE) [5]. Interferon-stimulated gene factor 3 (ISGF3; a heterotrimer of signal transducer and activator of transcription (STAT)1, STAT2, and interferon regulatory factor (IRF) 9) bound to the distal responsive element and NF- $\kappa \mathrm{B}$ bound to the proximal responsive element have been shown to cooperate to induce iNOS expression [6]. Several other transcription factors have been shown to regulate mouse iNOS transcription including 
IRF-1, Octamer factor (Oct-1), activating protein-1 (AP-1), and high-mobility group protein $\operatorname{HMG}-\mathrm{I}(\mathrm{Y})[2,7]$.

Transcriptional regulation of human iNOS expression shows complexity. Human iNOS promoter shows basal promoter activity, and regulatory elements involved in the cytokine-induced human iNOS transcription are located between -3.8 and $-16 \mathrm{~kb}$ upstream of the transcriptional start site $[7,8]$. A number of transcription factors contribute to human iNOS transcription. NF- $\kappa$ B and STAT1 are considered to be the key transcription factors regulating human iNOS transcription $[9,10]$. AP-1 has been reported to have positive and negative effects on human iNOS promoter activity $[11,12]$. Several other transcription factors have been shown to be involved in human iNOS transcription including Oct-1, cAMP-responsive element-binding protein, CCAAT-enhancer box-binding protein, STAT3, NF-IL6, and hypoxia-induced factor-1 [7].

Mitogen-activated protein kinases (MAPKs) have been shown to regulate iNOS expression, especially by posttranscriptional mechanisms. iNOS mRNA stability has been shown to be regulated by p38 MAPK and Jun N-terminal kinase (JNK) [13-15]. Other factors involved in the regulation of iNOS expression at posttranscriptional level include transforming growth factor $\beta$, glucocorticoids, and inhibitors of calcineurin [16-18]. Proteins that bind to the $3^{\prime}$ untranslated region of iNOS mRNA and regulate iNOS expression at posttranscriptional level include embryonic lethal abnormal visual RNA-binding protein $\mathrm{HuR}$, tristetraprolin, $\mathrm{KH}$ type splicing regulatory protein, and heterogeneous nuclear ribonucleoprotein D and I [13, 19-22].

MAPKs are a group of serine/threonine protein kinases involved in the cellular signal transduction, and the members of this signalling pathway group include p38 MAPK, JNK and p42/44 ERK. They are activated via phosphorylation of specific tyrosine and threonine residues by the upstream kinases. MAPKs regulate various physiological processes, including cell growth, differentiation, and stress responses, and p38 and JNK are associated with the regulation of inflammatory and immune responses [23-25]. There are four p38 MAPK isoforms (p38 $\alpha, \mathrm{p} 38 \beta, \mathrm{p} 38 \gamma$, and $\mathrm{p} 38 \delta)$, all encoded by separate genes. Especially p $38 \alpha$ and p $38 \beta$ have been found to regulate immune response [24-26]. Many different stimuli, including LPS, cytokines and growth factors, activate p38 MAPK pathway [27-31]. The activation of p38 MAPK is involved in the expression of several inflammatory genes, such as tumor necrosis factor (TNF), interleukin(IL)-1, IL-6, IL-8, cyclooxygenase-2 (COX-2) and iNOS $[13,26,27,32-35]$. p38 MAPK inhibitors have been shown to suppress the expression of inflammatory cytokines, progression of arthritis, and pulmonary fibrosis in animal models and attenuate inflammatory response during endotoxemia in humans [36-38].

Dual specificity phosphatases (DUSPs) are a group of protein phosphatases that dephosphorylate phosphotyrosine and phosphoserine/threonine residues in their target proteins and regulate several intracellular signaling pathways. DUSPs associated with MAPK pathways (at least ten members) differ from each other by substrate specificity, tissue distribution, cellular localization, and expressional pattern
$[39,40]$. DUSP1 dephosphorylates tyrosine and threonine residues in MAPK Thr-Xaa-Tyr activation motif and thereby inactivates MAPK. DUSP1 has substrate specificity towards p38 and JNK over ERK [41-44]. DUSP1 deficient mice produce elevated levels of inflammatory cytokines and develop more severe NO-mediated hypotensive response and organ failure after administration of LPS or peptidoglycan and lipoteichoic acid [41, 43, 45, 46].

We have previously reported that DUSP1 negatively regulates IL-6, IL-8 and COX-2 expression in A549 human epithelial cells [47]. In addition, we have recently shown that the suppression of the expression of COX-2, matrix metalloproteinase 3 (MMP-3), and IL-6 by antirheumatic drug aurothiomalate in mouse and human chondrocytes and cartilage is mediated by DUSP1 [48]. In the present study, we investigated the effect of DUSP1 on the expression of iNOS in human and murine cells. The main finding was that DUSP1 suppresses iNOS expression by limiting p38 signaling in human cells, which is a novel finding, and this was observed in mouse macrophages also.

\section{Materials and Methods}

2.1. Materials. Reagents were obtained as follows. BIRB 796 (1-(5-tertbutyl-2-p-tolyl-2H-pyrazol-3-yl)-3(4-(2-morpholin-4-yl-ethoxy)naphthalen-1-yl)urea, Axon MedChem, Groningen, The Netherlands), SB202190 (4-[4-(4-Fluorophenyl)-5-(4-pyridinyl)-1H-imidazol-2-yl] phenol, Tocris Bioscience, Bristol, UK), recombinant human TNF, recombinant human IFN $\gamma$, recombinant human IL- $1 \beta$, recombinant mouse macrophage colony-stimulating factor (M-CSF) (R\&D Systems Inc., Minneapolis, Mass, USA), medetomidine (Domitor $1 \mathrm{mg} / \mathrm{mL}$, Orion Oyj, Espoo, Finland), and ketamine (Ketalar 10 mg/mL, Pfizer Oy Animal Health, Helsinki, Finland) were obtained as indicated. All other reagents were purchased from Sigma Chemicals Co. (Saint Louis, Mo, USA) unless otherwise stated below.

2.2. Cell Culture. A549 human lung epithelial cells (ATCC, Manassas, Va, USA) were cultured at $37^{\circ} \mathrm{C}$ in $5 \% \mathrm{CO}_{2}$ atmosphere in Ham's F12K (Kaighn's modification) medium supplemented with 5\% heat-inactivated fetal bovine serum (FBS), $100 \mathrm{U} / \mathrm{mL}$ penicillin, $100 \mu \mathrm{g} / \mathrm{mL}$ streptomycin, and $250 \mathrm{ng} / \mathrm{mL}$ amphotericin B (all from Invitrogen, Paisley, UK). J774 macrophages (ATCC, Manassas, Va, USA) were cultured at $37^{\circ} \mathrm{C}$ in $5 \% \mathrm{CO}_{2}$ atmosphere in Dulbecco's modified Eagle's medium with Ultraglutamine 1 (Lonza, Verviers Sprl, Verviers, Belgium) supplemented with 5\% heat-inactivated FBS, $100 \mathrm{U} / \mathrm{ml}$ penicillin, $100 \mu \mathrm{g} / \mathrm{mL}$ streptomycin, and $250 \mathrm{ng} / \mathrm{mL}$ amphotericin $\mathrm{B}$.

For experiments, A549 cells $\left(4 \times 10^{5}\right.$ cells/well $)$ were seeded on a 24 -well plate and grown for $48 \mathrm{~h}$ prior to the experiments. J774 cells $\left(2 \times 10^{5}\right.$ cells/well $)$ were seeded on a 24 -well plate and grown for $72 \mathrm{~h}$ prior to the experiments. BIRB 796 and SB202190 were dissolved in DMSO. BIRB 796, SB202190 at concentrations indicated, or DMSO (v/v 0.1\%) were added to the cells in fresh culture medium containing $5 \%$ FBS and antibiotics $30 \mathrm{~min}$ prior to the stimulation with a cytokine mixture containing TNF, IFN $\gamma$, and IL- $1 \beta$ 
$(10 \mathrm{ng} / \mathrm{mL}$ each) or LPS $(10 \mathrm{ng} / \mathrm{mL})$. Cells were further incubated for the time indicated.

\subsection{Animals and Isolation and Culture of Bone Marrow} Macrophages. Murine bone marrow macrophages (BMMs) were obtained from wild-type and DUSP1 $1^{(-l-)}$ C57BL/6 mice. Inbred C57BL/6 DUSP $1^{(-/-)}$mice were originally generated by the R. Bravo laboratory at Bristol-Myers Squibb Pharmaceutical Research Institute [49], and the wild-type mice originated from the same strain. The study was approved by the Animal Care and Use Committee of the University of Tampere and the respective provincial committee for animal experiments. Female mice aged 10-12 weeks were used in the study. The mice were anesthetized by intraperitoneal injection of $0.05 \mathrm{mg} / 100 \mathrm{~g}$ body weight of medetomidine and $7.5 \mathrm{mg} / 100 \mathrm{~g}$ body weight of ketamine. Finally, mice were euthanized by cervical dislocation. Bone marrow cells were obtained by aspiration with sterile syringe needle from femur and fibia. BMMs were generated from bone marrow cells with 5-7 days of incubation in RPMI 1640 medium supplemented with $10 \%$ heat-inactivated fetal calf serum (FCS), $100 \mathrm{U} / \mathrm{mL}$ penicillin, $100 \mu \mathrm{g} / \mathrm{mL}$ streptomycin and $10 \mathrm{ng} / \mathrm{mL} \mathrm{M-CSF}$. BMMs $\left(1 \times 10^{6}\right.$ cells/well $)$ were then seeded on a 24-well plate and cultured overnight in complete culture medium. BMMs were then serum-starved overnight. In the beginning of the experiment, LPS was added to the cells along with the culture medium containing 10\% FCS and antibiotics, and BMMs were incubated for the time indicated.

2.4. Preparation of Cell Lysates for Western Blot Analysis. At the indicated time points, culture medium was removed. Cells were rapidly washed with ice cold PBS and solubilized in cold lysis buffer containing $10 \mathrm{mM}$ Tris- $\mathrm{HCl}$, $5 \mathrm{mM}$ EDTA, $50 \mathrm{mM} \mathrm{NaCl}, 1 \%$ Triton-X-100, $0.5 \mathrm{mM}$ phenylmethylsulfonyl fluoride, $1 \mathrm{mM}$ sodiumorthovanadate, $20 \mu \mathrm{g} / \mathrm{mL}$ leupeptin, $50 \mu \mathrm{g} / \mathrm{mL}$ aprotinin, $5 \mathrm{mM}$ sodium fluoride, $2 \mathrm{mM}$ sodium pyrophosphate, and $10 \mu \mathrm{M} n$-octylD-glucopyranoside. After incubation for $20 \mathrm{~min}$ on ice, lysates were centrifuged $(12000 \mathrm{~g}, 10 \mathrm{~min}$ ) and supernatants were collected, mixed in a ratio of $1: 4$ with SDS loading buffer $(62.5 \mathrm{mM}$ Tris-HCl, pH 6.8, 10\% glycerol, $2 \%$ SDS, $0,025 \%$ bromophenol blue, and 5\% mercaptoethanol) and stored at $-20^{\circ} \mathrm{C}$ until analyzed. Protein concentrations in the samples were measured by the Coomassie blue method.

2.5. Western Blotting. Actin (sc-1616-R), DUSP1 (M-18, sc1102), lamin A/C (sc-20681), and polyclonal antirabbit (sc2004) and polyclonal antigoat (sc-2020) antibodies were obtained from Santa Cruz Biotechnology (Santa Cruz, Calif, USA). Phospho-p38 MAPK (Cat. no. 9218), p38 MAPK (Cat. no. 9212), mitogen-activated protein kinase-activated protein kinase 2 (MK2) (Cat. no. 3042) and phospho-MK2 (27B7, Cat. no. 3007) antibodies (Cell Signaling Technology Inc, Beverly, Mass, USA) were obtained as indicated. Prior to Western blot analysis, the protein samples were boiled for $10 \mathrm{~min}$. Equal aliquots of protein $(10-20 \mu \mathrm{g})$ were loaded on a $10 \%$ SDS-polyacrylamide electrophoresis gel and separated by electrophoresis. Proteins were transferred to
Hybond enhanced chemiluminescence nitrocellulose membrane (Amersham, Buckinghamshire, UK) by semidry electroblotting. After transfer, the membrane was blocked in TBS/T (20 mM Tris-base pH 7.6, $150 \mathrm{mM} \mathrm{NaCl}$, and $0.1 \%$ Tween-20) containing 5\% nonfat milk for $1 \mathrm{~h}$ at room temperature. For detection of phospho-proteins, membranes were blocked in TBS/T containing $5 \%$ bovine serum albumin. Membranes were incubated overnight at $4^{\circ} \mathrm{C}$ with the primary antibody and for $1 \mathrm{~h}$ with the secondary antibody in room temperature, and the chemiluminescent signal was detected by ImageQuant LAS 4000 mini (GE Healthcare BioSciences AB, Uppsala, Sweden). The chemiluminescent signal was quantified with ImageQuant TL 7.0 Image Analysis Software.

2.6. NO Measurement. Cells were incubated with compounds of interest for $24 \mathrm{~h}$. Culture medium was then collected, and nitrite (a stable metabolite of $\mathrm{NO}$ in aqueous conditions) levels were measured by the Griess reaction.

2.7. RNA Extraction and Quantitative RT-PCR. Primers and probes for quantitative RT-PCR were obtained from Metabion International AG (Martinsried, Germany). At the indicated time points, culture medium was removed and total RNA extraction was carried out with GenElute Mammalian Total RNA Miniprep Kit (Sigma-Aldrich, St Louis, Mo, USA) according to the manufacturer's instructions. Total RNA was reverse-transcribed to cDNA using TaqMan Reverse Transcription reagents and random hexamers (Applied Biosystems, Foster City, Calif, USA). cDNA obtained from the RT-reaction was diluted 1: 20 with RNAse-free water and was subjected to quantitative PCR using TaqMan Universal PCR Master Mix and ABI PRISM 7000 Sequence detection system (Applied Biosystems, Foster City, Calif, USA). The primer and probe sequences and concentrations (Table 1) were optimized according to manufacturer's guidelines in TaqMan Universal PCR Master Mix Protocol part number 4304449 revision C. Expression of human Lamin A/C mRNA and human DUSP1 mRNA were measured using TagMan Gene Expression Assays (Applied Biosystems, Foster City, Calif, USA). PCR reaction parameters were as follows: incubation at $50^{\circ} \mathrm{C}$ for $2 \mathrm{~min}$, incubation at $95^{\circ} \mathrm{C}$ for $10 \mathrm{~min}$, and thereafter 40 cycles of denaturation at $95^{\circ} \mathrm{C}$ for $15 \mathrm{~s}$ and annealing and extension at $60^{\circ} \mathrm{C}$ for $1 \mathrm{~min}$. Each sample was determined in duplicate. A standard curve method was used to determine the relative mRNA levels as described in the Applied Biosystems User Bulletin: A standard curve for each gene was created using RNA isolated from A549 cells stimulated with cytokines (TNF, IL$1 \beta$, and IFN $\gamma ; 10 \mathrm{ng} / \mathrm{mL}$ each) and $\mathrm{J} 774$ cells stimulated with LPS $(10 \mathrm{ng} / \mathrm{mL})$. Isolated RNA was reverse-transcribed, and dilution series of cDNA ranging from $1 \mathrm{pg}$ to $10 \mathrm{ng}$ were subjected to real-time PCR. The obtained threshold cycle values were plotted against the dilution factor to create a standard curve. Relative mRNA levels in test samples were then calculated from the standard curve.

2.8. Downregulation of DUSP1 by siRNA. Human DUSP1 siRNA 1 (Cat. no. J-003484-09-0005) and human DUSP1 
TABle 1: Primer and probe sequences for quantitative RT-PCR.

\begin{tabular}{|c|c|c|c|}
\hline Gene & Oligonucleotide & Sequence & Conc. (nM) \\
\hline \multirow{3}{*}{ Human GAPDH } & Forward primer & TCCTACCACCAGCAACCCTGCCA & 300 \\
\hline & Reverse primer & GCAACAATATCCACTTTACCAGAGTTAA & 300 \\
\hline & Probe & CGCCTGGTCACCAGGGCTGC & 150 \\
\hline \multirow{3}{*}{ Human iNOS } & Forward primer & GCAGGTCGACTATTTCTTTCA & 300 \\
\hline & Reverse primer & TCCTCCTCCGCCTCGTAAGGA & 300 \\
\hline & Probe & TCAAGAGCCAGAAGCGCTATCACGAAGATA & 150 \\
\hline \multirow{3}{*}{ Mouse GAPDH } & Forward primer & GCATGGCCTTCCGTGTTC & 300 \\
\hline & Reverse primer & GATGTCATCATACTTGGCAGGTTT & 300 \\
\hline & Probe & TCGTGGATCTGACGTGCCGCC & 150 \\
\hline \multirow{3}{*}{ Mouse iNOS } & Forward primer & CCTGGTACGGGCATTGCT & 300 \\
\hline & Reverse primer & GCTCATGCGGCCTCCTT & 300 \\
\hline & Probe & CAGCAGCGGCTCCATGACTCCC & 150 \\
\hline \multirow{3}{*}{ Mouse DUSP1 } & Forward primer & CTCCTGGTTCAACGAGGCTATT & 300 \\
\hline & Reverse primer & TGCCGGCCTGGCAAT & 300 \\
\hline & Probe & CCATCAAGGATGCTGGAGGGAGAGTGTT & 150 \\
\hline
\end{tabular}

siRNA 2 (Cat. no. J-003484-10-0005) were purchased from Dharmacon (Dharmacon, Lafayette, Colo, USA). Lamin A/C siRNA (Cat. no. 1022050,) and nontargeting control siRNA (Cat. no. 1022076) were purchased from QIAGEN (QIAGEN, Valencia, Calif, USA). Mouse DUSP1 was silenced using ON-TARGET SMART pool (Dharmacon, Cat. no. L-040753-00-0005). siCONTROL nontargeting siRNA \#1 (Dharmacon, Cat. no. D-001210-01) was used as a negative control siRNA in J774 cells.

A549 cells were transfected with siRNA using HiPerFect transfection Reagent (QIAGEN) according to the manufacturer's instructions. Briefly, cells $\left(1.25 \times 10^{5}\right.$ cells/well $)$ were seeded on a 24 -well plate in $500 \mu \mathrm{L}$ of medium with $5 \%$ FBS without antibiotics. For one well, $3 \mu \mathrm{L}$ of siRNA stock solution $(2 \mu \mathrm{M})$ was mixed with $1.5 \mu \mathrm{L}$ of transfection reagent in final volume of $100 \mu \mathrm{L}$ of medium, incubated for $5 \mathrm{~min}$ in room temperature, and applied over the cells. Cells were further incubated for $48 \mathrm{~h}$. Fresh culture medium was changed and cytokines were added into the culture medium. Cells were further incubated for the time indicated, and gene expression was analyzed.

J774 cells were transfected with siRNA using DharmaFECT 4 transfection reagent (Dharmacon, Lafayette, Colo, USA) according to the manufacturer's instructions. Briefly, cells $\left(1 \times 10^{5}\right.$ cells/well $)$ were seeded on a 24 -well plate in $500 \mu \mathrm{L}$ of medium with 5\% FBS without antibiotics and incubated overnight. For one well, the final transfection medium applied to the cells contained $25 \mu \mathrm{L}$ of siRNA stock solution $(2 \mu \mathrm{M})$ mixed with $1 \mu \mathrm{L}$ of transfection reagent in final volume of $500 \mu \mathrm{L}$ of medium. Cells were further incubated for $48 \mathrm{~h}$. Fresh culture medium was changed, and LPS was added into the culture medium. Cells were further incubated for the time indicated, and gene expression was analyzed.

Transfection efficacy was monitored with green fluorescent siRNA oligos (siGLO green transfection indicator, Cat. no. D-001630-01, Dharmacon, Lafayette, Colo, USA) using
Nikon Eclipse TS100 microscope (Nikon, Tokyo, Japan). Approximately $90 \%$ of the cells emitted green fluorescence signal when transfected with siGLO and HiPerFect (A549 cells) or siGLO and DharmaFECT 4 (J774 cells). Less than $5 \%$ of the cells emitted signal when cells were incubated siGLO oligos without transfection reagent.

2.9. Statistics. Results are expressed as the mean \pm S.E.M. When appropriate, one-way ANOVA with Dunnett's or Bonferroni's post test was performed using GraphPad InStat version 3.05 for Windows 95/NT (GraphPad Software, San Diego, Calif, USA). Differences were considered significant at ${ }^{*} P<.05,{ }^{* *} P<.01$, and ${ }^{* * *} P<.001$.

\section{Results}

3.1. p38 MAPK Inhibitors SB202190 and BIRB 796 Downregulated iNOS Expression and NO Production in Response to Inflammatory Stimuli in A549 Cells and J774 Cells. A549 pulmonary epithelial cells and J774 macrophages were stimulated with a cytokine mixture (TNF, IFN $\gamma$, and IL$1 \beta ; 10 \mathrm{ng} / \mathrm{mL}$ each) and LPS $(10 \mathrm{ng} / \mathrm{mL})$, respectively, for the time indicated. Cells were then harvested for protein extraction, and the phosphorylation of p38 MAPK was detected by Western blot. p38 MAPK phosphorylation was increased in response to stimulation at time point of $30 \mathrm{~min}$, and it was returned to the basal level in $1 \mathrm{~h}$ (Figure 1(a)). p38 MAPK inhibitors SB202190 and BIRB 796 have been reported to effectively inhibit p38 MAPK at $1 \mu \mathrm{M}$ and $100 \mathrm{nM}$ concentrations, respectively [50]. To confirm the inhibiting effect of SB202190 and BIRB 796 on p38 MAPK activity in the current experimental condition, their effect on the phosphorylation of p38 MAPK substrate MK2 $(47 \mathrm{kDa})$ was investigated in A549 cells and J774 cells. Cells were preincubated with p38 MAPK inhibitors SB202190 or BIRB 796 for $30 \mathrm{~min}$ and stimulated with the cytokine mixture or LPS for $30 \mathrm{~min}$. The phosphorylation of MK2 was detected 

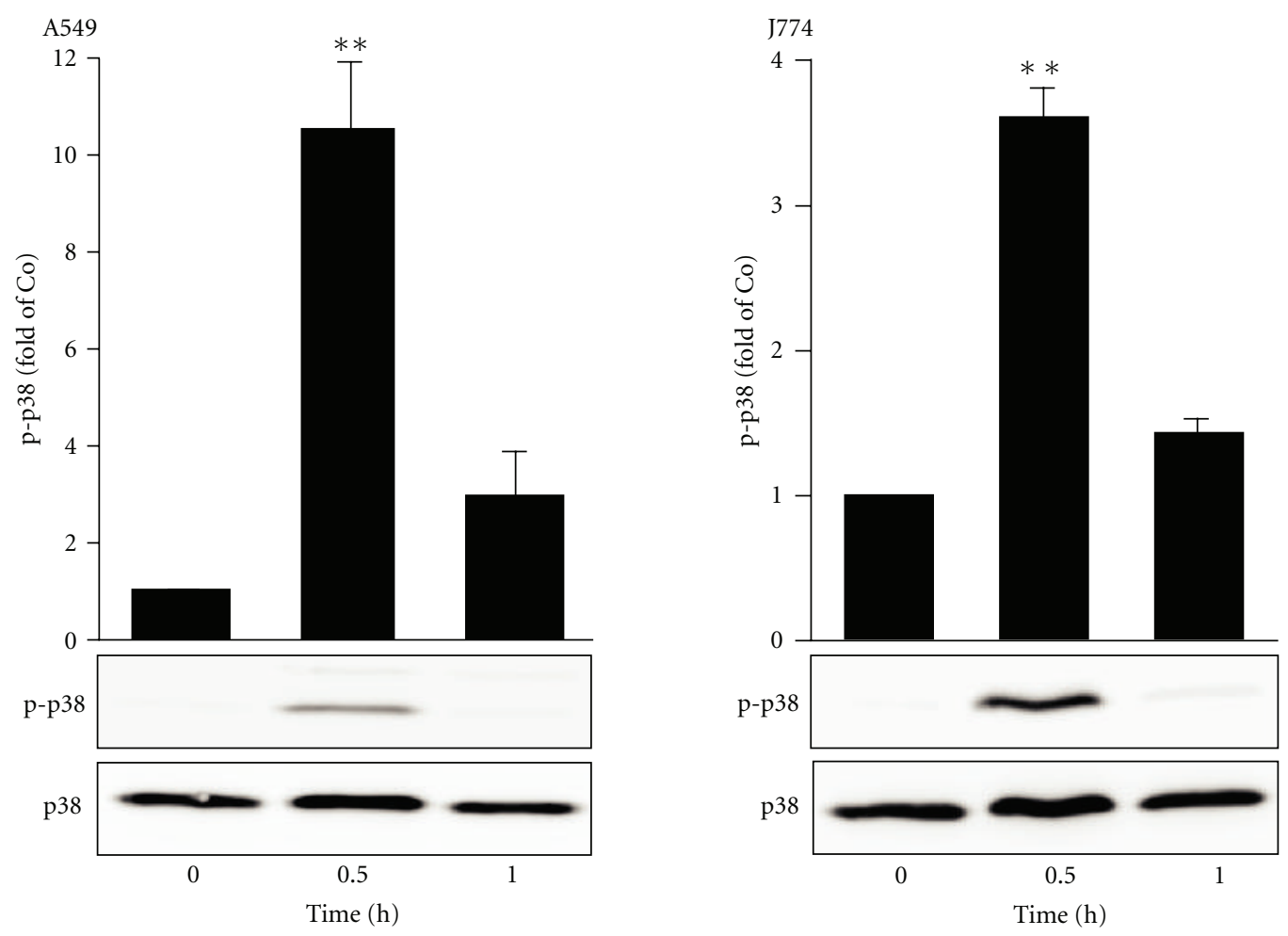

(a)
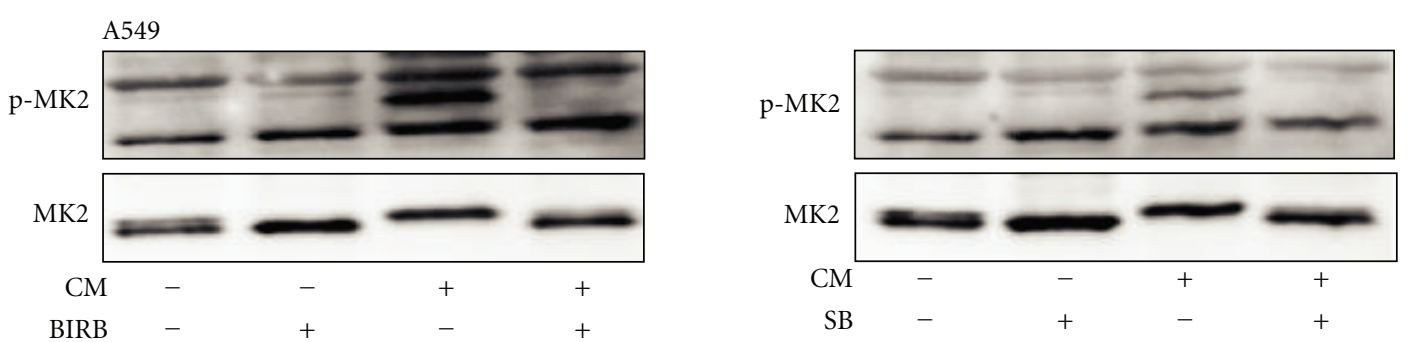

(b)



(c)

FIGURE 1: Phosphorylation of p38 MAPK and its substrate MK2 in response to stimulation with cytokine mixture or LPS in A549 and J774 cells. (a) A549 and J774 cells were stimulated with the cytokine mixture (CM: TNF, IFN $\gamma$, and IL- $1 \beta$; $10 \mathrm{ng} / \mathrm{mL}$ each) or LPS (10 ng/mL), respectively for the time indicated. Cells were then harvested for protein extraction, and phosphorylation of p38 MAPK was detected by Western blot. The gel is a representative of six separate experiments with similar results. Chemiluminescent signal was quantified, and phosphorylated p38 MAPK was normalized against total p38 MAPK. Phosphorylation levels are expressed in arbitrary units, unstimulated cells set as 1 , and the other values are related to that. Results are expressed as mean \pm S.E.M.; $n=6$. One-way ANOVA with Dunnett's posttest was performed, and statistical significance was indicated with ${ }^{* *} P<.01$ compared with unstimulated cells. ((b) and (c)) The effect of SB202190 and BIRB 796 on the phosphorylation of MK2 in response to cytokine mixture in A549 and J774 cells. Cells were preincubated with SB202190 $(1 \mu \mathrm{M})$ or BIRB $796(100 \mathrm{nM})$ for $30 \mathrm{~min}$ and stimulated with cytokine mixture (A549 cells) or LPS (J774 cells) for 30 min, and the phosphorylation of MK2 was detected by Western blot. The gels are representatives of six separate experiments with similar results. 


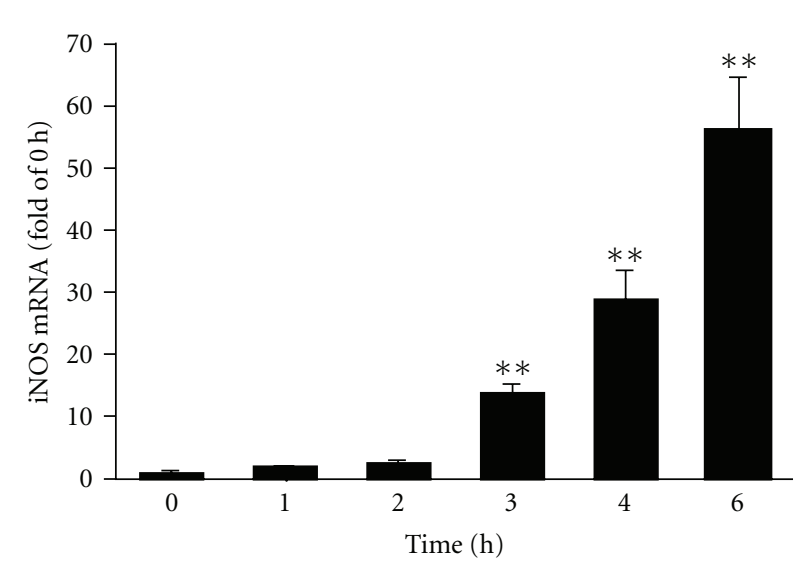

(a)

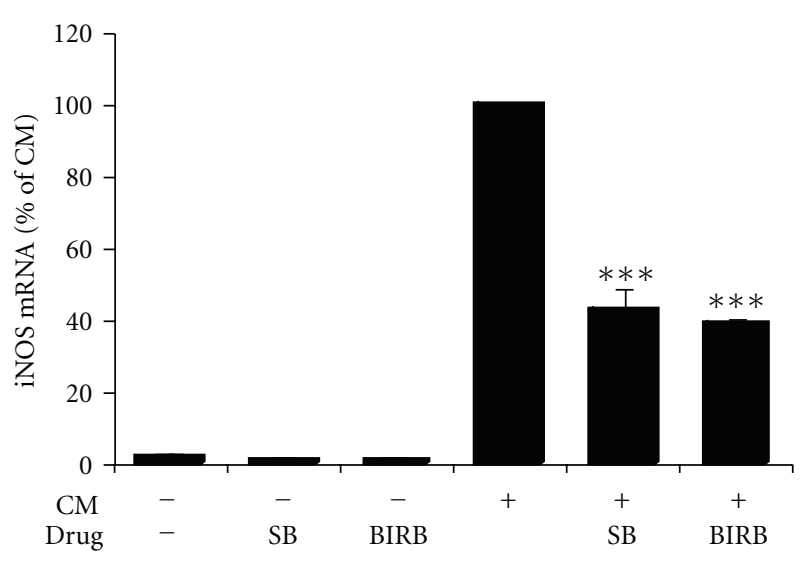

(b)

FIGURE 2: Expression of iNOS mRNA over time and effects of SB202190 and BIRB 796 on the expression of iNOS mRNA in response to cytokine mixture in A549 cells. (a) Cells were stimulated with cytokine mixture (CM: TNF, IFN $\gamma$, and IL- $1 \beta$; $10 \mathrm{ng} / \mathrm{mL}$ each) for the time indicated, and total RNA was extracted. The expression of iNOS mRNA was determined by quantitative real-time RT-PCR, and mRNA expression was normalized against GAPDH mRNA. Unstimulated cells $(0 \mathrm{~h})$ were set as 1 , and other values were related to that. Results are expressed as mean \pm S.E.M., $n=3$. One-way ANOVA with Dunnett's posttest was performed, and statistical significance is indicated with ${ }^{* *} P<.01$ as compared to unstimulated cells. (b) Cells were preincubated with SB202190 (1 $\mu$ M) or BIRB 796 (100 nM) for $30 \mathrm{~min}$, stimulated with cytokine mixture for $6 \mathrm{~h}$, and harvested for total RNA extraction. The expression of iNOS mRNA was determined by quantitative real-time RT-PCR, and mRNA expression was normalized against GAPDH mRNA. Results are expressed as a percentage of CM, mean \pm S.E.M., $n=6$. One-way ANOVA with Bonferroni's posttest was performed, and statistical significance is indicated with $* * * P<.001$ as compared to cells treated with CM.

by Western blot. SB202190 and BIRB 796 inhibited MK2 phosphorylation at concentrations of $1 \mu \mathrm{M}$ and $100 \mathrm{nM}$, respectively (Figures $1(\mathrm{~b})$ and $1(\mathrm{c})$ ). These results confirmed that SB202190 and BIRB 796, at concentrations used, inhibited p38 MAPK function.

The expression of iNOS mRNA over time was investigated in A549 cells. Cells were stimulated with the cytokine mixture for $0-6 \mathrm{~h}$, and iNOS mRNA levels were measured. iNOS mRNA expression was increased in response to the stimulation with cytokine mixture up to $6 \mathrm{~h}$ (Figure 2(a)). The effect of p38 MAPK inhibitors on iNOS mRNA expression was investigated. Cells were preincubated with SB202190 $(1 \mu \mathrm{M})$ and BIRB $796(100 \mathrm{nM})$ for $30 \mathrm{~min}$ and stimulated for $6 \mathrm{~h}$. SB202190 and BIRB 796 inhibited the expression of iNOS mRNA in A549 cells (Figure 2(b)).

The effects of p38 MAPK inhibitors SB202190 and BIRB 796 on iNOS protein expression and NO production were investigated. Cells were preincubated with SB202190 or BIRB 796 for $30 \mathrm{~min}$ and stimulated with the cytokine mixture (A549 cells) or LPS (J774 cells) for $24 \mathrm{~h}$. Supernatants were collected and total cellular proteins were extracted for determination of nitrite production (a stable metabolite of $\mathrm{NO}$ in aqueous solution) and iNOS protein expression, respectively. Unstimulated cells did not express detectable levels of iNOS or produce NO, and pretreatment with SB202190 or BIRB 796 alone did not induce iNOS expression or NO production. Stimulation with the cytokine mixture or LPS induced iNOS protein expression and NO production, and SB202190 and BIRB 796 inhibited iNOS expression and NO production in A549 cells (Figure 3) and J774 cells (Figure 4) in a dose-dependent manner.
3.2. DUSP1 Negatively Regulated the Phosphorylation of p38 MAPK. The expression of DUSP1 was investigated in A549 and J774 cells. A549 and J774 cells were stimulated with the cytokine mixture (TNF, IFN $\gamma$, and IL-1 $\beta$ ) and LPS, respectively, and cells were then harvested for total RNA or protein extraction at the time points indicated. Unstimulated cells showed low-level basal DUSP1 protein $(40 \mathrm{kDa})$ expression. DUSP1 mRNA and protein expression was enhanced by the cytokine mixture (A549 cells) or LPS (J774 cells). The maximal mRNA and protein expression was observed at $1 \mathrm{~h}$ after stimulation (Figure 5). DUSP1 mRNA expression was returned to basal level in $2 \mathrm{~h}$ in both cell types. DUSP1 protein expression was reduced near the basal level at $2 \mathrm{~h}$ and $3 \mathrm{~h}$ in A549 and J774 cells, respectively (Figure 5). In DUSP1 Western blots in A549 cells, an immunoreactive band of higher molecular weight was observed. The manufacturer's data sheet suggests this to be DUSP4. The immunoreactive band of higher molecular weight was not reduced by DUSP1 siRNA indicating that it is a molecule different from DUSP1 (Figure 6(a)).

To investigate the effect of DUSP1 on the phosphorylation of p38 MAPK, we used siRNA to downregulate DUSP1 expression. In A549 cells transfected with two DUSP1specific siRNAs, the protein and mRNA levels of DUSP1 were reduced as compared to the cells transfected with a nontargeting control siRNA showing that siRNA effectively downregulated DUSP1 (Figure 6(a)). The downregulation of DUSP1 by siRNA resulted in an increased p38 MAPK phosphorylation in response to stimulation at $1 \mathrm{~h}$ in A549 cells (Figure 6(a)). Lamin A/C siRNA, used as a positive control, downregulated lamin A/C mRNA by approximately 

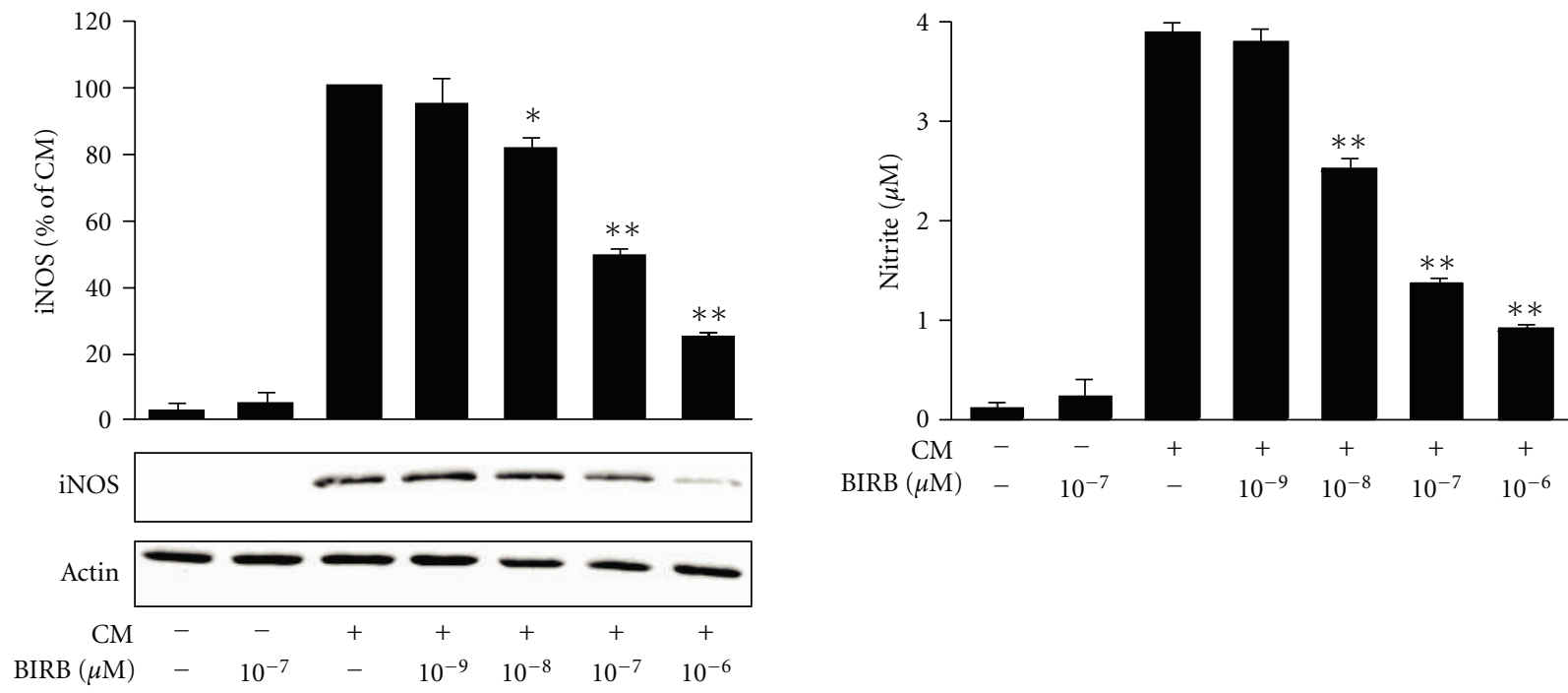

(a)
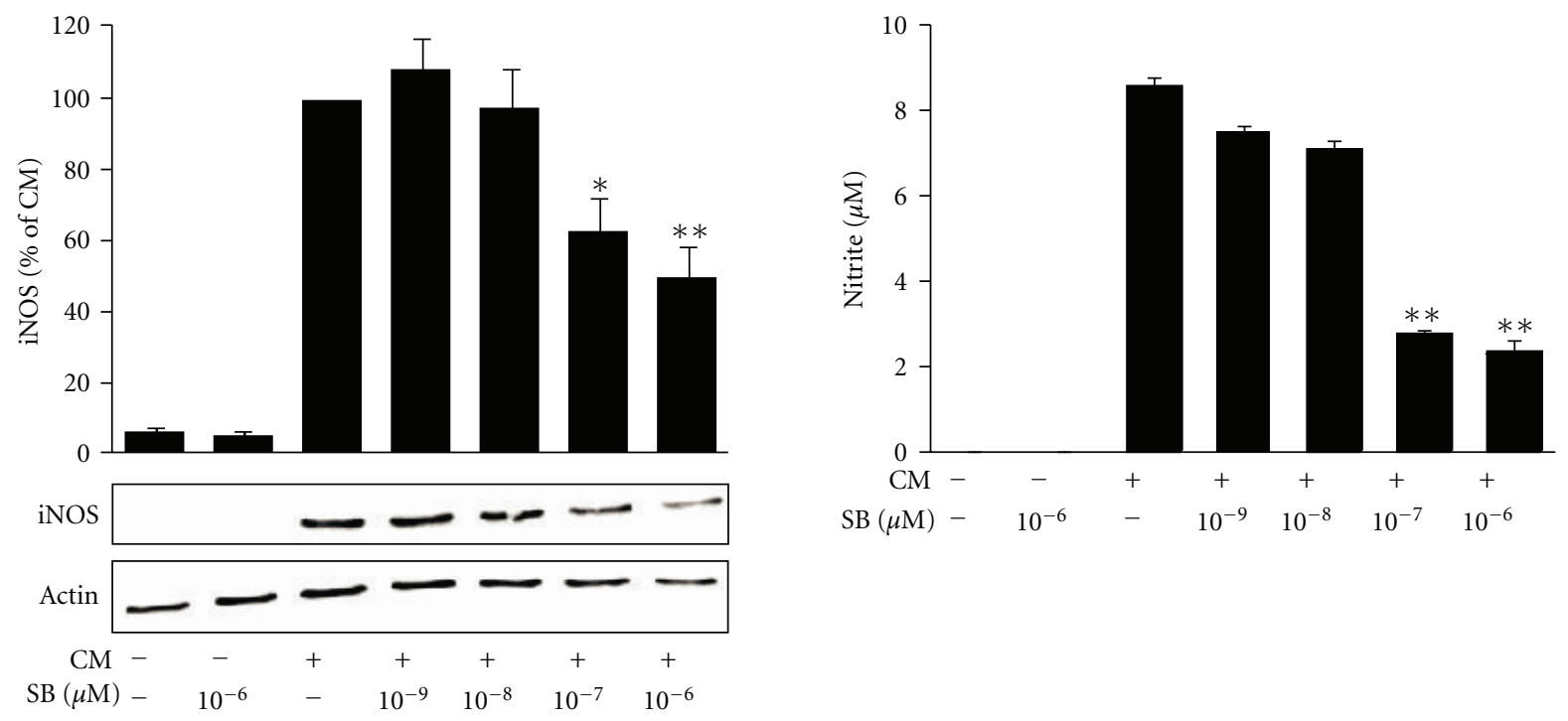

(b)

FIGURE 3: The effect of p38 MAPK inhibitors BIRB 796 and SB202190 on iNOS expression and NO production in response to cytokine mixture in A549 cells. A549 cells were preincubated with increasing concentrations of (a) BIRB 796 or (b) SB202190 for 30 min and stimulated with a cytokine mixture (CM: TNF, IFN $\gamma$, and IL-1 $\beta ; 10 \mathrm{ng} / \mathrm{mL}$ each) for $24 \mathrm{~h}$. iNOS expression was detected by Western blot. The gels are representatives of six separate experiments with similar results. Chemiluminescent signal was quantified, and iNOS (iNOS) expression was normalized to actin. NO production was measured as nitrite accumulated in the culture medium by Griess reaction. The results are expressed as mean \pm S.E.M., $n=6$. One-way ANOVA with Dunnett's posttest was performed, and statistical significance is indicated with ${ }^{*} P<.05$ and ${ }^{* *} P<.01$ compared to cells treated with CM.

$67 \%(n=3$, data not shown $)$, but it did not affect DUSP1 expression or p38 MAPK phosphorylation in A549 cells (Figure 6(a)). The effect of DUSP1 siRNA on DUSP1 expression and $\mathrm{p} 38$ MAPK phosphorylation was investigated in J774 cells also. DUSP1 siRNA inhibited DUSP1 mRNA and protein expression and enhanced p38 MAPK phosphorylation in J774 cells (Figure 6(b)). These results show that DUSP1 catalyzed the dephosphorylation of p38 MAPK and thereby inactivated p38 MAPK in A549 and J774 cells.
3.3. DUSP1 Negatively Regulated iNOS Expression and NO Production. The effect of down-regulation of DUSP1 on iNOS expression and NO production in response to the cytokine mixture (TNF, IFN $\gamma$, and IL- $1 \beta$; A549 cells) or LPS (J774 cells) was investigated. A549 cells were transfected with two DUSP1-specific siRNA. Cells were then stimulated with the cytokine mixture for $6 \mathrm{~h}$ (iNOS mRNA analysis) and $24 \mathrm{~h}$ (iNOS protein analysis and NO production). Silencing of DUSP1 by siRNA resulted in increased iNOS mRNA and 


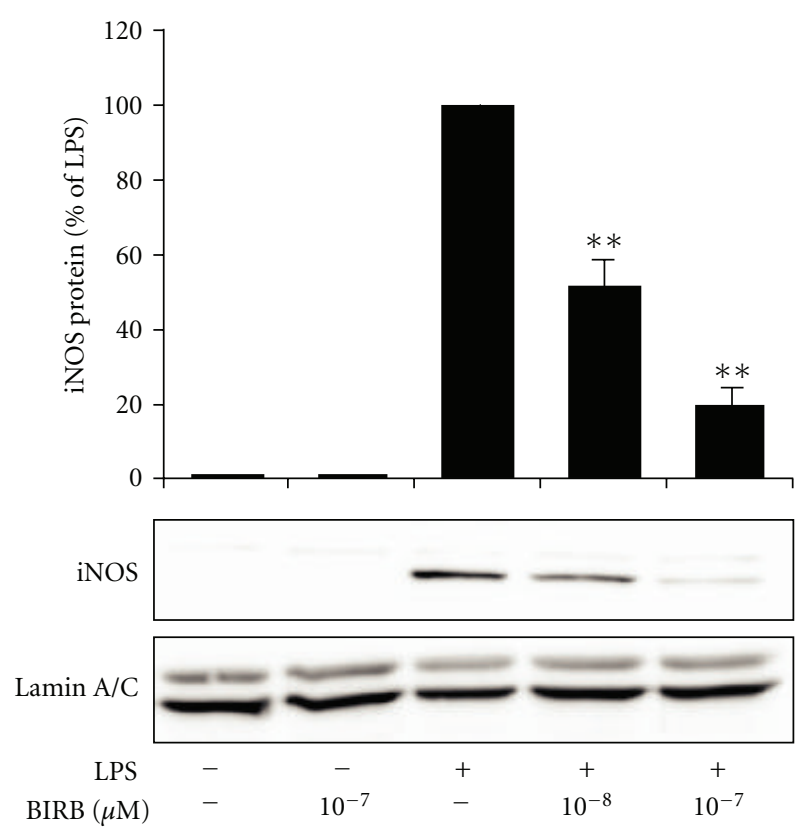

(a)



(b)

FIGURE 4: The effect of p38 MAPK inhibitor BIRB 796 on mouse iNOS protein expression and NO production in response to LPS in J774 cells. J774 cells were preincubated with increasing concentrations of BIRB 796 for 30 min and stimulated with LPS ( $10 \mathrm{ng} / \mathrm{mL}$ ) for $24 \mathrm{~h}$. iNOS protein expression was detected with Western blot. Chemiluminescent signal was quantified, and iNOS expression was normalized to lamin. The gels are representatives of six separate experiments with similar results. Results are expressed as a percentage of LPS, mean \pm S.E.M., $n=6$. NO production was measured as nitrite accumulated in the culture medium by Griess reaction, and the results are expressed as mean \pm S.E.M., $n=6$. One-way ANOVA with Dunnett's posttest was performed, and statistical significance is indicated with $* * P<.01$ compared to LPS-treated cells.

protein expression and NO production in A549 cells (Figures $7(\mathrm{a})$ and $7(\mathrm{~b}))$. Human iNOS mRNA expression induced by cytokine mixture in untransfected cells was comparable to that seen in transfected cells (Figure 7(a)). Untransfected cells expressed human iNOS protein at somewhat higher level and produced slightly more $\mathrm{NO}$ as compared to the transfected cells (Figure 7(b)). Similarly, down-regulation of DUSP1 by siRNA increased iNOS protein expression in J774 cells (Figure 7(c)). In A549 cells, Lamin A/C-specific siRNA did not affect iNOS expression or NO production (Figures 7(a) and 7(b)) although it downregulated lamin A/C expression by about $70 \%$. This strongly suggests that the increased iNOS expression and NO production in A549 cells caused by DUSP1-specific siRNA (Figures 7(a) and 7(b)) were due to the down-regulation of DUSP1 and not to nonspecific effects of siRNA, or general activation of RNAinduced silencing complex (RISC) pathway.

To further confirm the effect of DUSP1 on iNOS expression, the induction of iNOS expression by LPS was investigated in bone marrow macrophages (BMMs) from DUSP $1^{(-/)}$and wild-type mice. BMMs were stimulated with LPS $(10 \mathrm{ng} / \mathrm{mL})$ for $24 \mathrm{~h}$. Cells were harvested for protein extraction, and iNOS expression was analyzed by Western blot. Unstimulated cells from wild-type and DUSP1 $1^{(-/)}$mice did not express detectable amounts of iNOS. LPS enhanced iNOS expression in BMMs, and LPSinduced iNOS expression was markedly enhanced in BMMs isolated from DUSP1 ${ }^{(-)}$mice as compared to cells from wild-type mice (Figure 8).

\section{Discussion}

In the present study, we investigated the effect of DUSP1 on the expression of iNOS and production of NO in response to stimulation with cytokines (TNF, IFN $\gamma$, and IL-1 $\beta$ ) in human A549 lung epithelial cells and with LPS in murine J774 macrophages and primary mouse BMMs. The main finding of this study was that DUSP1 negatively regulates iNOS expression and NO production by inhibiting the p38 MAPK phosphorylation both in mouse and human cells. This is the first study showing that DUSP1 regulates iNOS expression in human cells.

Structurally distinct p38 MAPK inhibitors SB202190 and BIRB 796 have been reported to inhibit p38 MAPK at concentration range of $100 \mathrm{nM}$ to $1 \mu \mathrm{M}$ in kinase assays [50]. We have previously reported that SB202190 and BIRB 796 inhibit phosphorylation of MK2 (a p38 MAPK substrate) in a dose-dependent manner with maximal inhibition at $1 \mu \mathrm{M}$ and $100 \mathrm{nM}$ concentrations, respectively [47]. In the present study, SB202190 and BIRB 796 inhibited MK2 phosphorylation at these concentrations showing that both these inhibitors effectively inhibited p38 MAPK function in A549 and J774 cells. iNOS mRNA expression was reduced by both p38 MAPK inhibitors at these concentrations in A549 cells. 

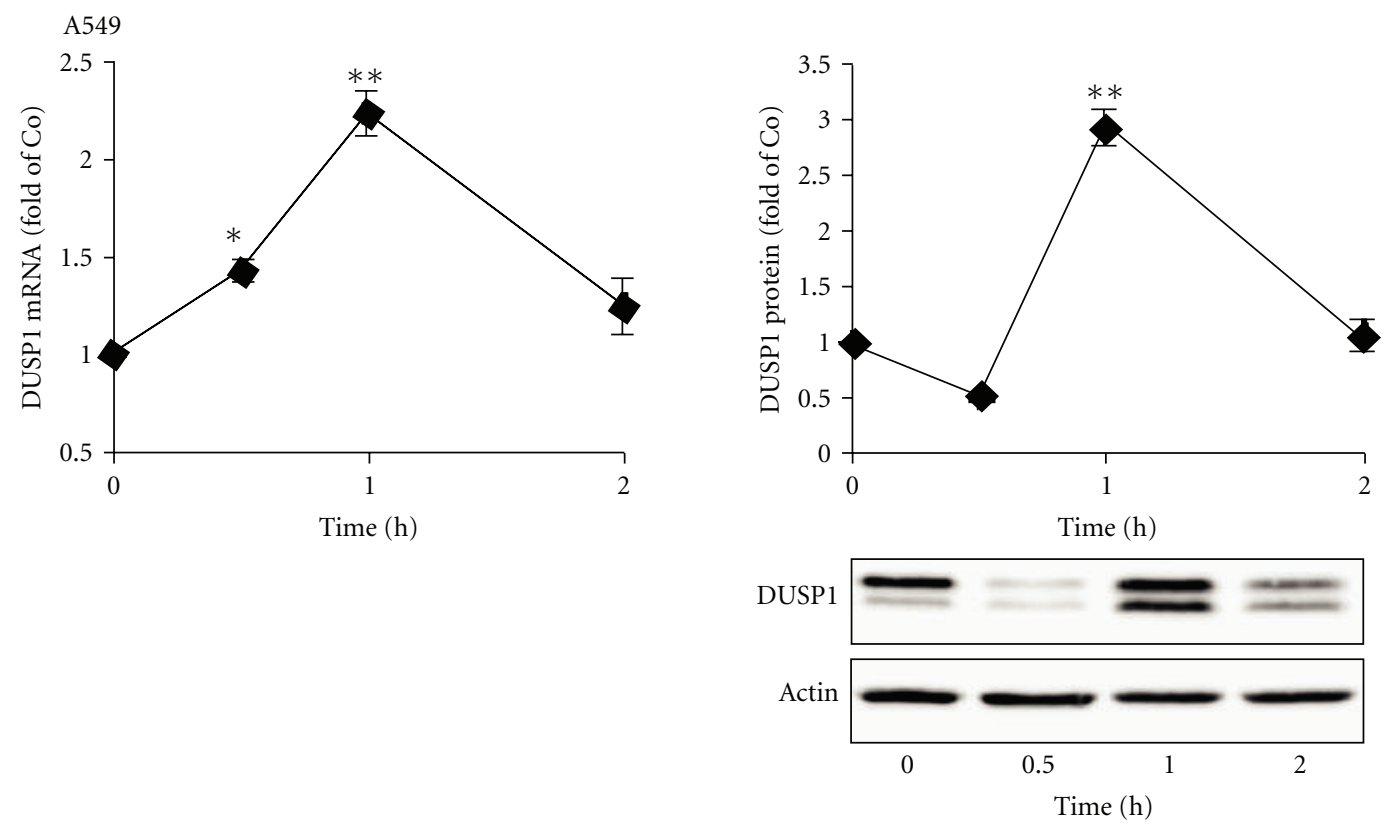

(a)
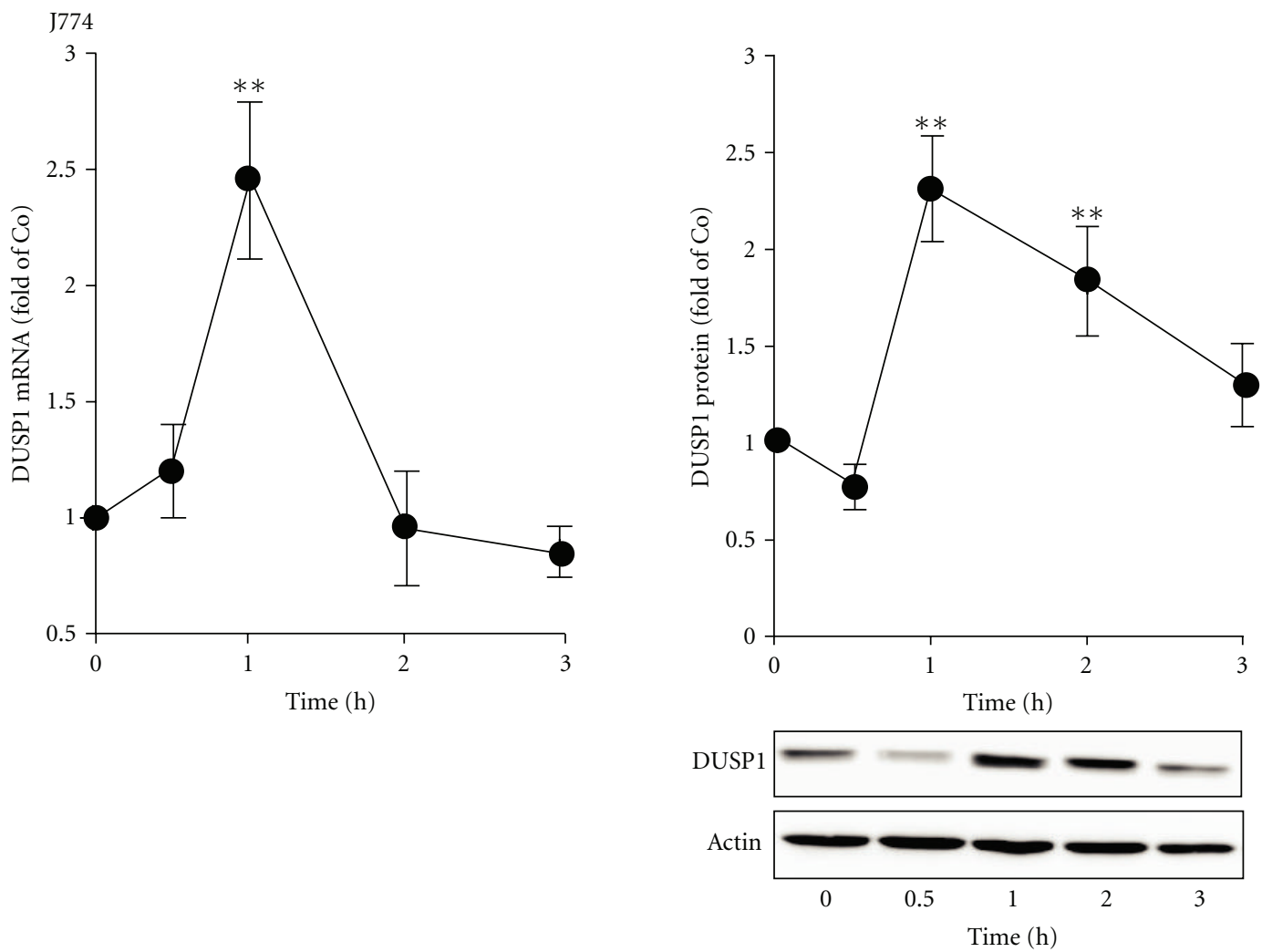

(b)

FIGURE 5: Expression of DUSP1 in response to cytokine mixture or LPS in A549 and J774 cells. Cells were stimulated with (a) cytokines (CM: TNF, IFN $\gamma$, and IL- $1 \beta ; 10 \mathrm{ng} / \mathrm{mL}$ each) or (b) LPS $(10 \mathrm{ng} / \mathrm{mL})$ for the time indicated, and DUSP1 mRNA and protein expression was determined by quantitative real-time RT-PCR and Western blot, respectively. DUSP1 mRNA expression was normalized against GAPDH mRNA. In Western blots, chemiluminescent signal was quantified and DUSP1 protein expression was normalized against actin. The gels are representatives of six separate experiments with similar results. DUSP1 protein and mRNA levels are expressed in arbitrary units, DUSP1 expression in unstimulated cells $(0 \mathrm{~h})$ is set as 1 , and the other values are related to that (mean \pm S.E.M.; $n=6)$. One-way ANOVA with Dunnett's posttest was performed, and statistical significance is indicated with ${ }^{*} P<.05$ and $* * P<.01$ compared with unstimulated cells. 




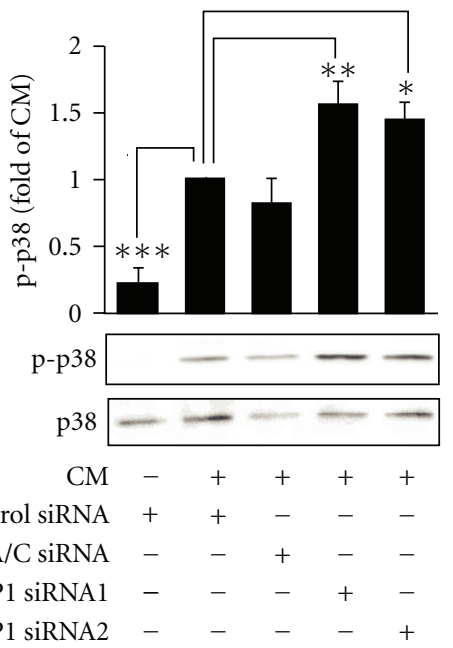

(a)

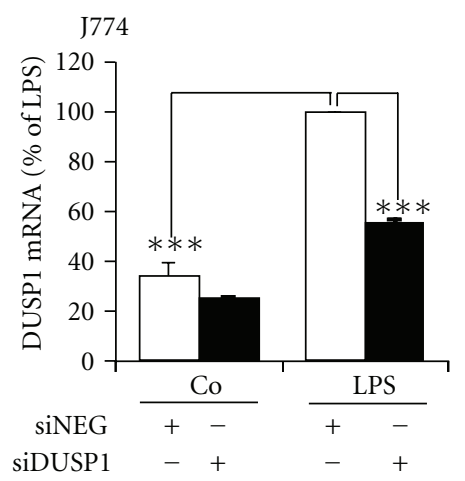

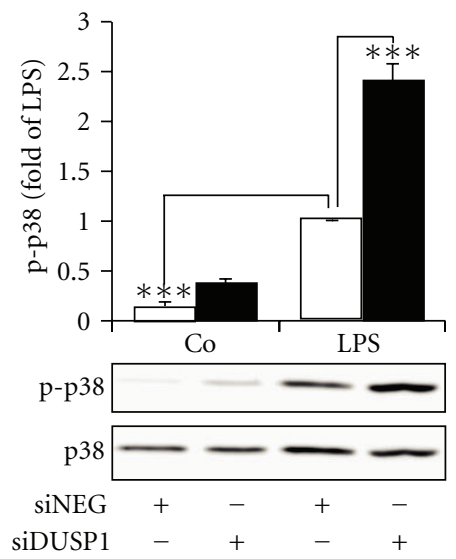

(b)

Figure 6: The effect of DUSP1 siRNA on DUSP1 expression and p38 MAPK phosphorylation in A549 and J774 cells. (a) A549 cells were transfected with DUSP1-specific siRNA 1 or 2 (DUSP1 siRNA 1 or 2), nontargeting control siRNA (control siRNA), or Lamin A/Cspecific siRNA (Lamin A/C siRNA). (b) J774 cells were transfected with DUSP1-specific siRNA (siMKP-1) or nontargeting siRNA (siNEG). Cells were stimulated with cytokines (CM: TNF, IFN $\gamma$, and IL- $1 \beta ; 10 \mathrm{ng} / \mathrm{mL}$ each) or LPS (10 ng/mL) for $1 \mathrm{~h}$. DUSP1 mRNA expression was determined by quantitative real-time RT-PCR and normalized against GAPDH mRNA. DUSP1 protein expression and p38 MAPK phosphorylation were determined by Western blot. Chemiluminescent signal was quantified and DUSP1 expression was normalized against actin, and phosphorylated p38 MAPK was normalized against total p38 MAPK. Results are expressed as a percentage of CM or LPS. One-way ANOVA with Bonferroni's posttest was performed, and statistical significance is indicated with $* P<.05,{ }^{* *} P<.01$, and ${ }^{* * *} P<.001, n=6$, except for DUSP1 mRNA in J774 cells, $n=3$.

Also, iNOS protein expression and NO production were reduced by SB202190 and BIRB 796 in a dose-dependent manner in both A549 and J774 cells. iNOS expression has been reported to be inhibited by a p38 MAPK inhibitor SB203580, a compound structurally related to SB202190, at corresponding concentrations in human cells [13], and by SB203580 and SB202190 in J774 cells [35].

DUSPs are protein phosphatases capable to dephosphorylate tyrosine and threonine/serine residues and, hence, regulate the activity of their target proteins. A subgroup of DUSPs target MAPKs and dephosphorylate tyrosine and threonine residues in MAPKs. Currently, at least ten MAPKassociated DUSPs have been identified and they differ from each other by substrate specificity, tissue distribution, cellular localization, and expressional pattern $[40,44]$. DUSP1 is a nuclear phosphatase inducible by LPS and cytokines, and it has substrate specificity towards p38 MAPK and JNK. DUSP1 has been shown to regulate the phosphorylation of p38 MAPK and JNK in primary mouse macrophages $[42,43,51]$ and endothelial cells [52]. We have recently 


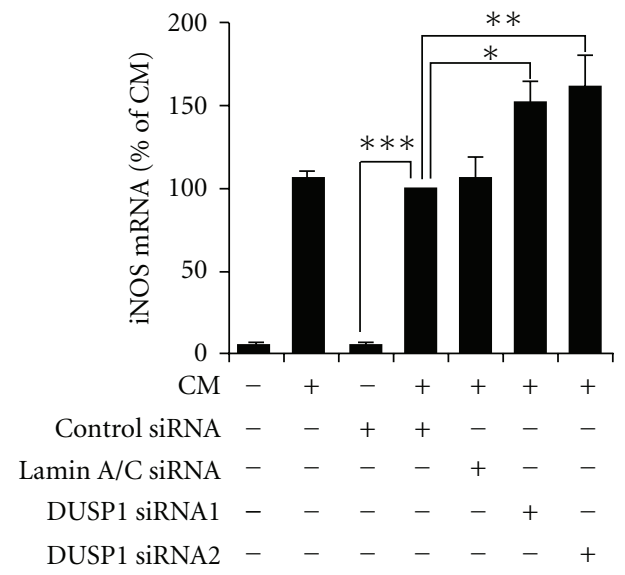

(a)
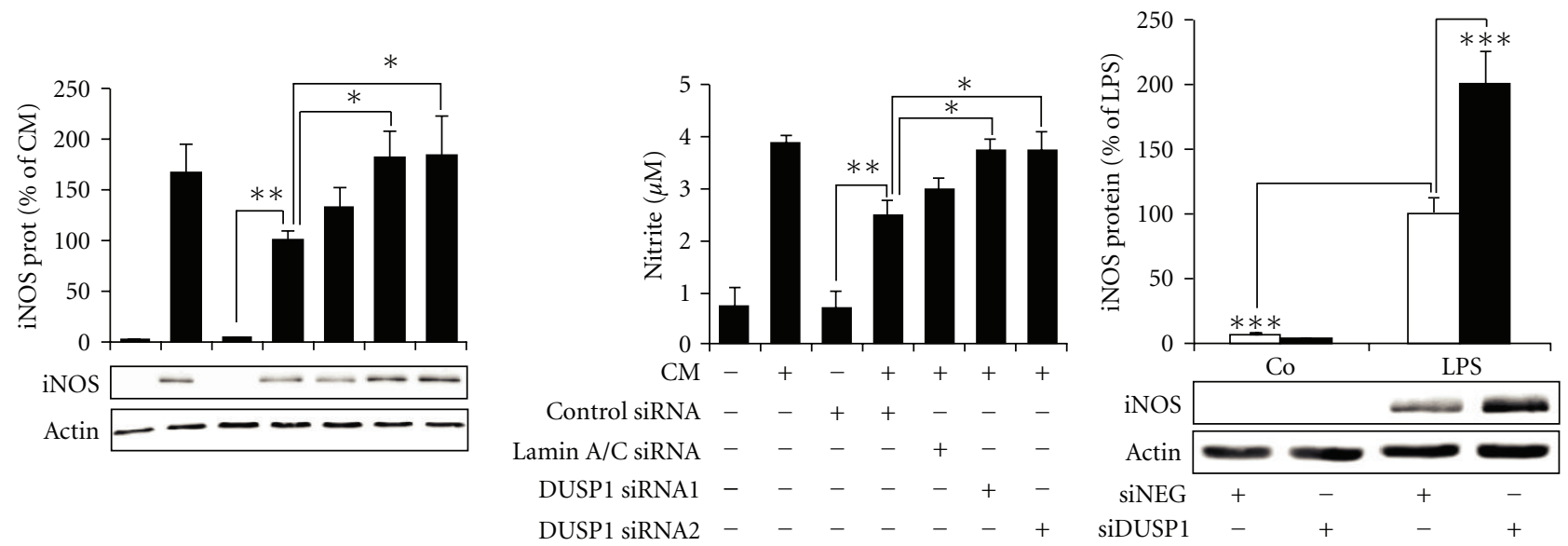

(b)

(c)

Figure 7: The effect of DUSP1 siRNA on iNOS mRNA and protein expression and NO production in A549 and J774 cells. A549 cells were transfected with DUSP1-specific siRNA 1 or 2 (DUSP1 siRNA 1 or 2), nontargeting control siRNA (control siRNA) or Lamin A/Cspecific siRNA (Lamin A/C siRNA), and untransfected cells were used as controls. (a) Cells were stimulated with the cytokine mixture (CM: TNF, IFN $\gamma$, and IL- $1 \beta ; 10 \mathrm{ng} / \mathrm{mL}$ each) for $6 \mathrm{~h}$, and iNOS mRNA was determined with quantitative real-time PCR and normalized against GAPDH mRNA. (b) Cells were stimulated with CM for $24 \mathrm{~h}$, and iNOS protein expression was detected by Western blot and NO production as nitrite by Griess reaction. (c) J774 cells were transfected either with DUSP1-specific siRNA (siDUSP1) or nontargeting siRNA (siNEG). Cells were stimulated with LPS $(10 \mathrm{ng} / \mathrm{mL})$ for $24 \mathrm{~h}$, and iNOS protein expression was detected by Western blot. In Western blots, chemiluminescent signal was quantified and iNOS expression was normalized against actin. Results are expressed as related to cells treated with CM or LPS. One-way ANOVA with Bonferroni's posttest was performed, and statistical significance is indicated with $* P<.05 ; * * P<.01$ and $* * * P<.001, n=6$.

reported that DUSP1 regulates the phosphorylation of both p38 MAPK and JNK in A549 human pulmonary epithelial cells [47] and p38 MAPK in chondrocytes [48]. In the present study, stimulation with cytokines or LPS enhanced the expression of DUSP1 in A549 and J774 cells. Transfection of DUSP1-specific siRNA decreased DUSP1 protein and mRNA expression and resulted in enhanced p38 MAPK phosphorylation, iNOS expression, and NO production in A549 cells. This is the first report showing that DUSP1 regulates human iNOS expression.
Down-regulation of DUSP1 by siRNA increased iNOS expression also in murine macrophages. Accordingly, LPSinduced iNOS expression was enhanced in BMMs isolated from DUSP1-deficient mice, which confirmed our results with cells in which DUSP1 had been silenced with siRNA. These results are also in line with the previous reports showing that iNOS expression is increased in DUSP1deficient mice in response to low-dose LPS administration or septicemia due to Gram-positive bacteria in vivo $[45,46]$. Interestingly, E. coli infection in DUSP1-deficient mice was 

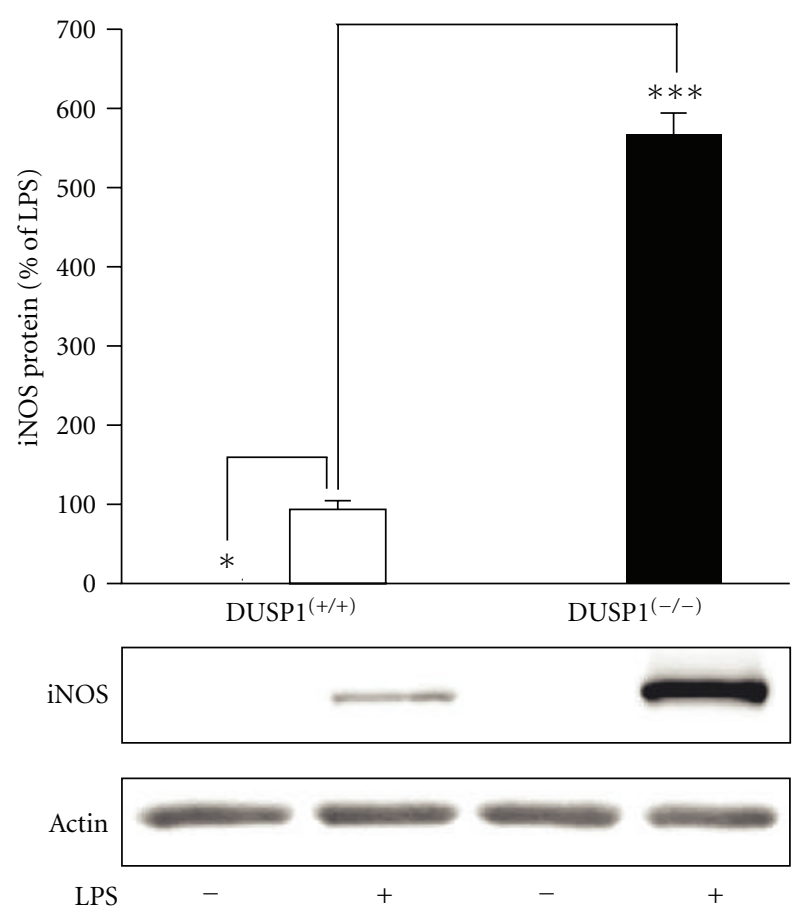

FIGURE 8: iNOS protein expression in bone marrow macrophages from wild-type and DUSP1-deficient mice. Bone marrowderived macrophages differentiated from wild-type (DUSP $1^{+/+}$ and DUSP1-deficient (DUSP1 $1^{-/-}$) mice were incubated with LPS $(10 \mathrm{ng} / \mathrm{mL})$ for $24 \mathrm{~h}$, and iNOS protein was measured by Western blot. The gels are representatives of three separate experiments with similar results. Chemiluminescent signal was quantified, and iNOS expression was normalized to actin. Results are expressed as a percentage of LPS, mean \pm S.E.M. $(n=3)$. One-way ANOVA with Bonferroni's posttest was performed, and statistical significance is indicated with ${ }^{*} P<.05$ and ${ }^{* * *} P<.001$.

reported to result in reduced serum nitrate levels and lower iNOS expression in liver as compared to wild-type mice [53]. These conflicting findings may reflect the differences in innate immune response to purified cell wall component (LPS) of Gram-negative bacteria and viable bacteria.

Translation of the results describing the mechanisms of mouse iNOS expression to that of human is not always straightforward. The size of the iNOS promoter differs greatly between mouse $(\sim 1.5 \mathrm{~kb})$ and human (up to $16 \mathrm{~kb}$ ). LPS and IFN $\gamma$ induce mouse iNOS promoter activity 50100-fold [5]. Human iNOS promoter shows low basal activity in the absence of measurable mRNA [19, 54]. Cytokine stimulation increases human iNOS promoter activity only approximately 7 -to- 10 fold, while mRNA expression increases more than 100 -fold $[8,19]$. This demonstrates the differences in transcriptional but also in posttranscriptional regulation of iNOS expression between mouse and human cells. From a therapeutic point of view, the mechanisms regulating iNOS expression ought to be applicable for human iNOS expression. In this study, we demonstrated the negative regulation of human iNOS expression by DUSP1, which has not previously been reported. Also, DUSP1 regulated mouse iNOS expression. According to our results, p38 MAPK/DUSP1 pathway seems to be a conserved signaling/regulatory mechanism for iNOS expression across species despite the considerable other differences in the regulation of iNOS expression between mouse and human. p38 MAPK/DUSP1 pathway may regulate iNOS expression both at transcriptional and posttranscriptional levels. Human iNOS has been shown to be regulated by p38 MAPK by a mechanism dependent on the interaction between human iNOS mRNA $3^{\prime}$ untranslated region and tristetraprolin, an mRNA-binding protein. p38 MAPK positively regulates tristetraprolin, which stabilizes iNOS mRNA and leads to increased iNOS expression [13]. In addition, human and rodent iNOS promoter activity has also been reported to be regulated by p38 MAPK $[11,55,56]$.

Therapeutic approaches targeted to enhance DUSP1 expression or its function may provide a novel mechanism for anti-inflammatory treatment. Glucocorticoids enhance DUSP1 expression, and some of the anti-inflammatory effects of glucocorticoids, such as the inhibition of cytokine and chemokine expression, are mediated by DUSP1 $[57,58]$. In alveolar macrophages from patients with glucocorticoidresistant asthma, the expression of DUSP1 in response to glucocorticoids was reported to be reduced and, correspondingly, p38 MAPK phosphorylation was increased [59]. Also, disease-modifying antirheumatic drug aurothiomalate was recently found to enhance DUSP1 expression in chondrocytes and cartilage, and DUSP1 mediated its inhibitory effect on COX-2, IL-6, and matrix metalloproteinase 3 expression [48]. Interestingly, DUSP4, another MAPK-associated DUSP, has been reported to regulate inflammatory response via ERK and DUSP1. DUSP4-deficient mice were protected from the excessive inflammatory response during septic infection. These animals showed increased ERK phosphorylation due to DUSP4 deficiency. Increased ERK activity resulted in enhanced DUSP1 expression and, in turn, reduced TNF and IL-6 production by macrophages [60].

In addition to inflammatory conditions, increased iNOSderived NO production has been shown to be present in various solid tumors. Myeloid-derived suppressor cells (MDSCs) are a group of myeloid progenitor cells, immature macrophages, granulocytes, and dendritic cells capable of suppressing functions of T cells. In malignancies, they infiltrate in solid tumors and promote tumor growth. Tumorassociated monocytic MDSCs express iNOS at high level. iNOS-derived NO by MDSCs targets tumor infiltrating T cells and suppresses their functions by inhibiting T cell receptor signaling and Jak/STAT pathway activation and inducing $\mathrm{T}$ cell apoptosis. NO production is one of the central mechanisms by which MDSCs promote tumor growth [61]. IL-6 and granulocyte/monocyte colony-stimulating factor (GM-CSF) have been reported to induce the differentiation of MDSCs from peripheral blood mononuclear cells [62]. Interestingly, DUSP1 suppresses IL-6 and GM-CSF, expression $[41,47,63]$. DUSP1 may limit the differentiation and functions on MDSCs by suppressing the expression of IL-6, GM-CSF and iNOS. DUSP1 has been shown to be upregulated in early phases of epithelial carcinogenesis in bladder, colon, and prostate cancers with progressive loss on expression with higher histological grades and in metastasis 
[64]. In lung cancer, DUSP1 predicted improved survival [65]. In vitro, DUSP1 overexpression induced apoptosis at colon cancer cells [66]. These findings imply that DUSP1 may have antitumor activity. However, the antitumor effects of DUSP1 may well be related to the cancer type and the stage of the disease. It is noteworthy that DUSP1 has been recently linked to the depressive behavior in animal experiments [67], and if this appears to be the case also in humans, it may limit the therapeutic potential of DUSP1 in inflammatory and other conditions.

\section{Conclusions}

In conclusion, our results show that DUSP1 negatively regulated iNOS expression and NO production induced by inflammatory stimuli by inhibiting p38 MAPK phosphorylation in murine and human cells. This study extends our understanding on the role of DUSP1 in inflammation and on the mechanisms that regulate iNOS expression especially in human cells. This may give new insights in the development of novel drug treatments for diseases complicated with increased iNOS-mediated NO production.

\section{Abbreviations}

$\begin{array}{ll}\text { AP-1: } & \text { Activating protein-1 } \\ \text { BMMs: } & \text { bone marrow macrophages } \\ \text { COX-2: } & \text { Cyclooxygenase-2 } \\ \text { DUSP: } & \text { Dual specificity phosphatase } \\ \text { ERK: } & \text { Extracellular signal-regulated kinase } \\ \text { GAPDH: } & \text { Glyceraldehyde-3-phosphate dehydrogenase } \\ \text { GM-CSF: } & \text { Granulocyte/monocyte colony-stimulating } \\ & \text { factor } \\ \text { iNOS } & \text { Inducible nitric oxide synthase } \\ \text { IFN } \gamma: & \text { Interferon- } \gamma \\ \text { IRF: } & \text { Interferon-regulatory factor } \\ \text { IL: } & \text { Interleukin } \\ \text { JNK: } & \text { Jun N-terminal kinase } \\ \text { LPS: } & \text { Lipopolysaccharide } \\ \text { M-CSF: } & \text { Macrophage colony-stimulating factor } \\ \text { miRNA: } & \text { MicroRNA } \\ \text { MK2: } & \text { Mitogen-activated protein kinase-activated } \\ & \text { protein kinase } 2 \\ \text { MAPK: } & \text { Mitogen-activated protein kinase } \\ \text { MDSC: } & \text { Myeloid-derived suppressor cell } \\ \text { NO: } & \text { Nitric oxide } \\ \text { NOS: } & \text { Nitric oxide synthase } \\ \text { Oct-1: } & \text { Octamer factor } \\ \text { siRNA: } & \text { Small interfering RNA } \\ \text { TNF: } & \text { Tumor necrosis factor. }\end{array}$

\section{Acknowledgments}

The authors would like to thank Bristol-Myers Squibb Pharmaceutical Research Institute for providing DUSP1 knockout mice. Mrs Salla Hietakangas and Ms Meiju Kukkonen are warmly thanked for excellent technical assistance and Mrs Heli Määttä for skillful secretarial help. This work was financially supported by grants from Competitive Research
Funding of the Pirkanmaa Hospital District, Finland, from Tampere Tuberculosis Foundation, Finland, and from Scandinavian Rheumatology Research Foundation.

\section{References}

[1] C. Bogdan, "Nitric oxide and the immune response," Nature Immunology, vol. 2, no. 10, pp. 907-916, 2001.

[2] R. Korhonen, A. Lahti, H. Kankaanranta, and E. Moilanen, "Nitric oxide production and signaling in inflammation," Current Drug Targets, vol. 4, no. 4, pp. 471-479, 2005.

[3] K. Vuolteenaho, T. Moilanen, R. G. Knowles, and E. Moilanen, "The role of nitric oxide in osteoarthritis," Scandinavian Journal of Rheumatology, vol. 36, no. 4, pp. 247-258, 2007.

[4] J. R. Kanwar, R. K. Kanwar, H. Burrow, and S. Baratchi, "Recent advances on the roles of NO in cancer and chronic inflammatory disorders," Current Medicinal Chemistry, vol. 16, no. 19, pp. 2373-2394, 2009.

[5] C. J. Lowenstein, E. W. Alley, P. Raval et al., "Macrophage nitric oxide synthase gene: two upstream regions mediate induction by interferon $\gamma$ and lipopolysaccharide," Proceedings of the National Academy of Sciences of the United States of America, vol. 90, no. 20, pp. 9730-9734, 1993.

[6] M. Farlik, B. Reutterer, C. Schindler et al., "Nonconventional initiation complex assembly by STAT and NF- $\kappa$ B transcription factors regulates nitric oxide synthase expression," Immunity, vol. 33, no. 1, pp. 25-34, 2010.

[7] A. Pautz, J. Art, S. Hahn, S. Nowag, C. Voss, and H. Kleinert, "Regulation of the expression of inducible nitric oxide synthase," Nitric Oxide, vol. 23, no. 2, pp. 75-93, 2010.

[8] M. E. De Vera, R. A. Shapiro, A. K. Nussler et al., "Transcriptional regulation of human inducible nitric oxide synthase (NOS2) gene by cytokines: initial analysis of the human NOS2 promoter," Proceedings of the National Academy of Sciences of the United States of America, vol. 93, no. 3, pp. 1054-1059, 1996.

[9] B. S. Taylor, M. E. de Vera, R. W. Ganster et al., "Multiple $\mathrm{NF}-\kappa \mathrm{B}$ enhancer elements regulate cytokine induction of the human inducible nitric oxide synthase gene," The Journal of Biological Chemistry, vol. 273, no. 24, pp. 15148-15156, 1998.

[10] R. W. Ganster, B. S. Taylor, L. Shao, and D. A. Geller, “Complex regulation of human inducible nitric oxide synthase gene transcription by Stat 1 and NF- $\kappa \mathrm{B}$," Proceedings of the National Academy of Sciences of the United States of America, vol. 98, no. 15, pp. 8638-8643, 2001.

[11] A. S. Kristof, J. Marks-Konczalik, and J. Moss, "Mitogenactivated protein kinases mediate activator protein-1dependent human inducible nitric-oxide synthase promoter activation," The Journal of Biological Chemistry, vol. 276, no. 11 , pp. 8445-8452, 2001.

[12] H. Kleinert, T. Wallerath, G. Fritz et al., "Cytokine induction of NO synthase II in human DLD-1 cells: roles of the JAKSTAT, AP-1 and NF- $\kappa$ B-signaling pathways," British Journal of Pharmacology, vol. 125, no. 1, pp. 193-201, 1998.

[13] M. Fechir, K. Linker, A. Pautz et al., "Tristetraprolin regulates the expression of the human inducible nitric-oxide synthase gene," Molecular Pharmacology, vol. 67, no. 6, pp. 2148-2161, 2005.

[14] R. Korhonen, K. Linker, A. Pautz, U. Förstermann, E. Moilanen, and H. Kleinert, "Post-transcriptional regulation of human inducible nitric-oxide synthase expression by the Jun N-terminal kinase," Molecular Pharmacology, vol. 71, no. 5, pp. 1427-1434, 2007. 
[15] A. Lahti, U. Jalonen, H. Kankaanranta, and E. Moilanen, "c-Jun NH-terminal kinase inhibitor anthra(1,9-cd)pyrazol$6(2 \mathrm{H})$-one reduces inducible nitric-oxide synthase expression by destabilizing mRNA in activated macrophages," Molecular Pharmacology, vol. 64, no. 2, pp. 308-315, 2003.

[16] Y. Vodovotz, C. Bogdan, J. Paik, Q. W. Xie, and C. Nathan, "Mechanisms of suppression of macrophage nitric oxide release by transforming growth factor $\beta$," Journal of Experimental Medicine, vol. 178, no. 2, pp. 605-613, 1993.

[17] R. Korhonen, A. Lahti, M. Hämäläinen, H. Kankaanranta, and E. Moilanen, "Dexamethasone inhibits inducible nitric-oxide synthase expression and nitric oxide production by destabilizing mRNA in lipopolysaccharide-treated macrophages," Molecular Pharmacology, vol. 62, no. 3, pp. 698-704, 2002.

[18] M. Hämäläinen, R. Korhonen, and E. Moilanen, "Calcineurin inhibitors down-regulate iNOS expression by destabilising mRNA," International Immunopharmacology, vol. 9, no. 2, pp. 159-167, 2009.

[19] F. Rodriguez-Pascual, M. Hausding, I. Ihrig-Biedert et al., "Complex contribution of the 3'-untranslated region to the expressional regulation of the human inducible nitric-oxide synthase gene: involvement of the RNA-binding protein HuR," The Journal of Biological Chemistry, vol. 275, no. 34, pp. 26040-26049, 2000.

[20] K. Linker, A. Pautz, M. Fechir, T. Hubrich, J. Greeve, and H. Kleinert, "Involvement of KSRP in the post-transcriptional regulation of human iNOS expression-complex interplay of KSRP with TTP and HuR," Nucleic Acids Research, vol. 33, no. 15, pp. 4813-4827, 2005.

[21] A. Pautz, K. Linker, T. Hubrich, R. Korhonen, S. Altenhöfer, and H. Kleinert, "The polypyrimidine tract-binding protein (PTB) is involved in the post-transcriptional regulation of human inducible nitric oxide synthase expression," The Journal of Biological Chemistry, vol. 281, no. 43, pp. 32294-32302, 2006.

[22] A. Pautz, K. Linker, S. Altenhöfer et al., "Similar regulation of human inducible nitric-oxide synthase expression by different isoforms of the RNA-binding protein AUF1," The Journal of Biological Chemistry, vol. 284, no. 5, pp. 2755-2766, 2009.

[23] G. L. Johnson and R. Lapadat, "Mitogen-activated protein kinase pathways mediated by ERK, JNK, and p38 protein kinases," Science, vol. 298, no. 5600, pp. 1911-1912, 2002.

[24] M. Rincón and R. J. Davis, "Regulation of the immune response by stress-activated protein kinases," Immunological Reviews, vol. 228, no. 1, pp. 212-224, 2009.

[25] A. Cuenda and S. Rousseau, "p38 MAP-Kinases pathway regulation, function and role in human diseases," Biochimica et Biophysica Acta, vol. 1773, no. 8, pp. 1358-1375, 2007.

[26] J. D. Ashwell, "The many paths to p38 mitogen-activated protein kinase activation in the immune system," Nature Reviews Immunology, vol. 6, no. 7, pp. 532-540, 2006.

[27] K. Ono and J. Han, "The p38 signal transduction pathway Activation and function," Cellular Signalling, vol. 12, no. 1, pp. $1-13,2000$.

[28] J. Han, J. D. Lee, L. Bibbs, and R. J. Ulevitch, "A MAP kinase targeted by endotoxin and hyperosmolarity in mammalian cells," Science, vol. 265, no. 5173, pp. 808-811, 1994.

[29] A. Pietersma, B. C. Tilly, M. Gaestel et al., "P38 mitogen activated protein kinase regulates endothelial VCAM-1 expression at the post-transcriptional level," Biochemical and Biophysical Research Communications, vol. 230, no. 1, pp. 44-48, 1997.

[30] I. N. Foltz, J. C. Lee, P. R. Young, and J. W. Schrader, "Hemopoietic growth factors with the exception of interleukin-4 activate the p38 mitogen-activated protein kinase pathway," The Journal of Biological Chemistry, vol. 272, no. 6, pp. 3296-3301, 1997.

[31] W. Wang, G. Zhou, M. C. T. Hu, Z. Yao, and T. H. Tan, "Activation of the hematopoietic progenitor kinase-1 (HPK1)-dependent, stress-activated c-Jun N-terminal kinase (JNK) pathway by transforming growth factor $\beta$ (TGF- $\beta$ )activated kinase (TAK1), a kinase mediator of TGF $\beta$ signal transduction," The Journal of Biological Chemistry, vol. 272, no. 36, pp. 22771-22775, 1997.

[32] C. Marie, S. Roman-Roman, and G. Rawadi, "Involvement of mitogen-activated protein kinase pathways in interleukin8 production by human monocytes and polymorphonuclear cells stimulated with lipopolysaccharide or Mycoplasma fermentans membrane lipoproteins," Infection and Immunity, vol. 67, no. 2, pp. 688-693, 1999.

[33] J. L. E. Dean, M. Brook, A. R. Clark, and J. Saklatvala, "p38 Mitogen-activated protein kinase regulates cyclooxygenase2 mRNA stability and transcription in lipopolysaccharidetreated human monocytes," The Journal of Biological Chemistry, vol. 274, no. 1, pp. 264-269, 1999.

[34] K. R. Mahtani, M. Brook, J. L. E. Dean, G. Sully, J. Saklatvala, and A. R. Clark, "Mitogen-activated protein kinase p38 controls the expression and posttranslational modification of tristetraprolin, a regulator of tumor necrosis factor alpha mRNA stability," Molecular and Cellular Biology, vol. 21, no. 19, pp. 6461-6469, 2001.

[35] A. Lahti, H. Kankaanranta, and E. Moilanen, "P38 mitogenactivated protein kinase inhibitor SB203580 has a bidirectional effect on iNOS expression and NO production," European Journal of Pharmacology, vol. 454, no. 2-3, pp. 115123, 2002.

[36] D. C. Underwood, R. R. Osborn, S. Bochnowicz et al., "SB 239063, a p38 MAPK inhibitor, reduces neutrophilia, inflammatory cytokines, MMP-9, and fibrosis in lung," American Journal of Physiology, vol. 279, no. 5, pp. L895-L902, 2000.

[37] A. M. Badger, D. E. Griswold, R. Kapadia et al., "Diseasemodifying activity of SB 242235, a selective inhibitor of p38 mitogen-activated protein kinase, in rat adjuvant-induced arthritis," Arthritis and Rheumatism, vol. 43, no. 1, pp. 175$183,2000$.

[38] B. L. Burnette, S. Selness, R. Devraj et al., "SD0006: a potent, selective and orally available inhibitor of p38 kinase," Pharmacology, vol. 84, no. 1, pp. 42-60, 2009.

[39] R. Lang, M. Hammer, and J. Mages, "DUSP meet immunology: dual specificity MAPK phosphatases in control of the inflammatory response," Journal of Immunology, vol. 177, no. 11 , pp. 7497-7504, 2006.

[40] T. Boutros, E. Chevet, and P. Metrakos, "Mitogen-Activated Protein (MAP) kinase/MAP kinase phosphatase regulation: roles in cell growth, death, and cancer," Pharmacological Reviews, vol. 60, no. 3, pp. 261-310, 2008.

[41] M. Hammer, J. Mages, H. Dietrich et al., "Dual specificity phosphatase 1 (DUSP1) regulates a subset of LPS-induced genes and protects mice from lethal endotoxin shock," Journal of Experimental Medicine, vol. 203, no. 1, pp. 15-20, 2006.

[42] K. V. Salojin, I. B. Owusu, K. A. Millerchip, M. Potter, K. A. Platt, and T. Oravecz, "Essential role of MAPK phosphatase-1 in the negative control of innate immune responses," Journal of Immunology, vol. 176, no. 3, pp. 1899-1907, 2006.

[43] H. Chi, S. P. Barry, R. J. Roth et al., "Dynamic regulation of pro- and anti-inflammatory cytokines by MAPK phosphatase 1 (MKP-1) in innate immune responses," Proceedings of the National Academy of Sciences of the United States of America, vol. 103, no. 7, pp. 2274-2279, 2006. 
[44] A. R. Clark, J. R. S. Martins, and C. R. Tchen, "Role of dual specificity phosphatases in biological responses to glucocorticoids," The Journal of Biological Chemistry, vol. 283, no. 38, pp. 25765-25769, 2008.

[45] T. J. Calvert, L. G. Chicoine, Y. Liu, and L. D. Nelin, "Deficiency of mitogen-activated protein kinase phosphatase1 results in iNOS-mediated hypotension in response to lowdose endotoxin," American Journal of Physiology, vol. 294, no. 4, pp. H1621-H1629, 2008.

[46] X. Wang, X. Meng, J. R. Kuhlman et al., "Knockout of Mkp1 enhances the host inflammatory responses to gram-positive bacteria," Journal of Immunology, vol. 178, no. 8, pp. 5312 5320, 2007.

[47] T. Turpeinen, R. Nieminen, E. Moilanen, and R. Korhonen, "Mitogen-activated protein kinase phosphatase-1 negatively regulates the expression of interleukin-6, interleukin-8, and cyclooxygenase-2 in A549 human lung epithelial cells," Journal of Pharmacology and Experimental Therapeutics, vol. 333, no. 1, pp. 310-318, 2010.

[48] R. Nieminen, R. Korhonen, T. Moilanen, A. R. Clark, and E. Moilanen, "Aurothiomalate inhibits cyclooxygenase 2, matrix metalloproteinase 3, and interleukin-6 expression in chondrocytes by increasing MAPK phosphatase 1 expression and decreasing p38 phosphorylation: MAPK phosphatase 1 as a novel target for antirheumatic drugs," Arthritis and Rheumatism, vol. 62, no. 6, pp. 1650-1659, 2010.

[49] K. Dorfman, D. Carrasco, M. Gruda, C. Ryan, S. A. Lira, and R. Bravo, "Disruption of the erp/mkp-1 gene does not affect mouse development: normal MAP kinase activity in ERP/MKP-1-deficient fibroblasts," Oncogene, vol. 13, no. 5, pp. 925-931, 1996.

[50] J. Bain, L. Plater, M. Elliott et al., "The selectivity of protein kinase inhibitors: a further update," Biochemical Journal, vol. 408, no. 3, pp. 297-315, 2007.

[51] Q. Zhao, X. Wang, L. D. Nelin et al., "MAP kinase phosphatase 1 controls innate immune responses and suppresses endotoxic shock," Journal of Experimental Medicine, vol. 203, no. 1, pp. 131-140, 2006.

[52] M. Zakkar, H. Chaudhury, G. Sandvik et al., "Increased endothelial mitogen-activated protein kinase phosphatase-1 expression suppresses proinflammatory activation at sites that are resistant to atherosclerosis," Circulation Research, vol. 103, no. 7, pp. 726-732, 2008.

[53] W. J. Frazier, X. Wang, L. M. Wancket et al., "Increased inflammation, impaired bacterial clearance, and metabolic disruption after gram-negative sepsis in Mkp-1-deficient mice," Journal of Immunology, vol. 183, no. 11, pp. 7411-7419, 2009.

[54] S. C. Linn, P. J. Morelli, I. Edry, S. E. Cottongim, C. Szabó, and A. L. Salzman, "Transcriptional regulation of human inducible nitric oxide synthase gene in an intestinal epithelial cell line," American Journal of Physiology, vol. 272, no. 6, pp. G1499G1508, 1997.

[55] T. Nakamura, H. Suzuki, Y. Wada, T. Kodama, and T. Doi, "Fucoidan induces nitric oxide production via p38 mitogenactivated protein kinase and NF- $\kappa \mathrm{B}$-dependent signaling pathways through macrophage scavenger receptors," Biochemical and Biophysical Research Communications, vol. 343, no. 1, pp. 286-294, 2006.

[56] K. Bellmann, V. Burkart, J. Bruckhoff, H. Kolb, and J. Landry, "p38-Dependent enhancement of cytokine-induced nitricoxide synthase gene expression by heat shock protein 70," The Journal of Biological Chemistry, vol. 275, no. 24, pp. 18172$18179,2000$.
[57] S. M. Abraham, T. Lawrence, A. Kleiman et al., "Antiinflammatory effects of dexamethasone are partly dependent on induction of dual specificity phosphatase 1," Journal of Experimental Medicine, vol. 203, no. 8, pp. 1883-1889, 2006.

[58] R. Issa, S. Xie, N. Khorasani et al., "Corticosteroid inhibition of growth-related oncogene protein- $\alpha$ via mitogen-activated kinase phosphatase-1 in airway smooth muscle cells," Journal of Immunology, vol. 178, no. 11, pp. 7366-7375, 2007.

[59] P. Bhavsar, M. Hew, N. Khorasani et al., "Relative corticosteroid insensitivity of alveolar macrophages in severe asthma compared with non-severe asthma," Thorax, vol. 63, no. 9, pp. 784-790, 2008.

[60] T. T. Cornell, P. Rodenhouse, Q. Cai, L. Sun, and T. P. Shanley, "Mitogen-activated protein kinase phosphatase 2 regulates the inflammatory response in sepsis," Infection and Immunity, vol. 78, no. 6, pp. 2868-2876, 2010.

[61] D. I. Gabrilovich and S. Nagaraj, "Myeloid-derived suppressor cells as regulators of the immune system," Nature Reviews Immunology, vol. 9, no. 3, pp. 162-174, 2009.

[62] M. G. Lechner, D. J. Liebertz, and A. L. Epstein, "Characterization of cytokine-induced myeloid-derived suppressor cells from normal human peripheral blood mononuclear cells," Journal of Immunology, vol. 185, no. 4, pp. 2273-2284, 2010.

[63] R. Newton, E. M. King, W. Gong et al., "Glucocorticoids inhibit IL-1beta-induced GM-CSF expression at multiple levels: roles for the ERK pathway and repression by MKP-1," The Biochemical Journal, vol. 427, no. 1, pp. 113-124, 2010.

[64] M. Loda, P. Capodieci, R. Mishra et al., "Expression of mitogen-activated protein kinase phosphatase-1 in the early phases of human epithelial carcinogenesis," American Journal of Pathology, vol. 149, no. 5, pp. 1553-1564, 1996.

[65] S. Vicent, M. Garayoa, J. M. López-Picazo et al., "Mitogenactivated protein kinase phosphatase-1 is overexpressed in non-small cell lung cancer and is an independent predictor of outcome in patients," Clinical Cancer Research, vol. 10, no. 11, pp. 3639-3649, 2004.

[66] Y. X. Liu, J. Wang, J. Guo, J. Wu, H. B. Lieberman, and Y. Yin, "DUSP1 is controlled by p53 during the cellular response to oxidative stress," Molecular Cancer Research, vol. 6, no. 4, pp. 624-633, 2008.

[67] V. Duric, M. Banasr, P. Licznerski et al., "A negative regulator of MAP kinase causes depressive behavior," Nature Medicine, vol. 16, no. 11, pp. 1328-1332, 2010. 


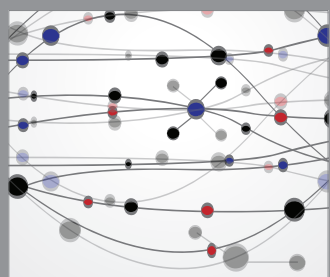

The Scientific World Journal
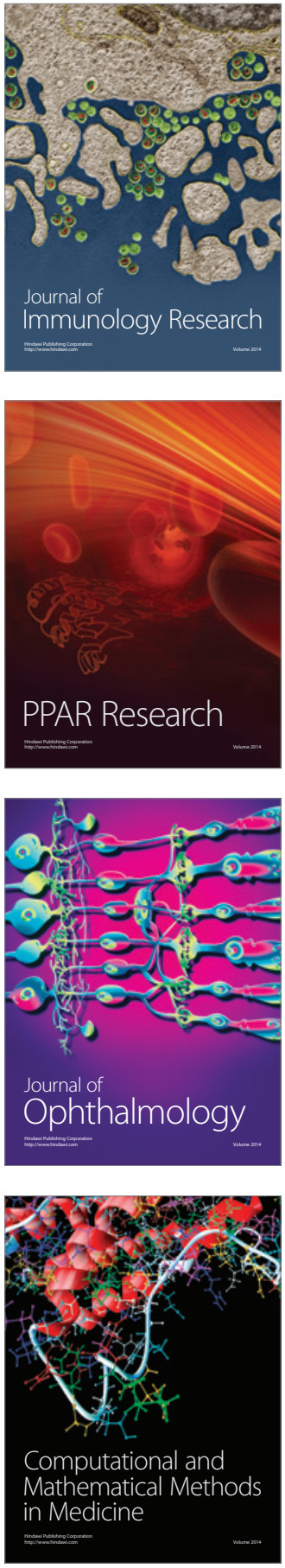

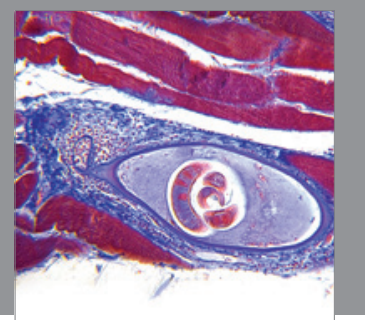

Gastroenterology

Research and Practice
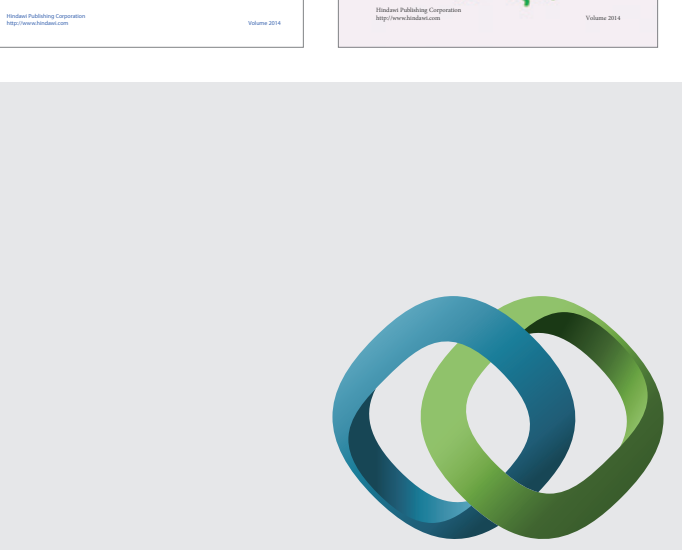

\section{Hindawi}

Submit your manuscripts at

http://www.hindawi.com
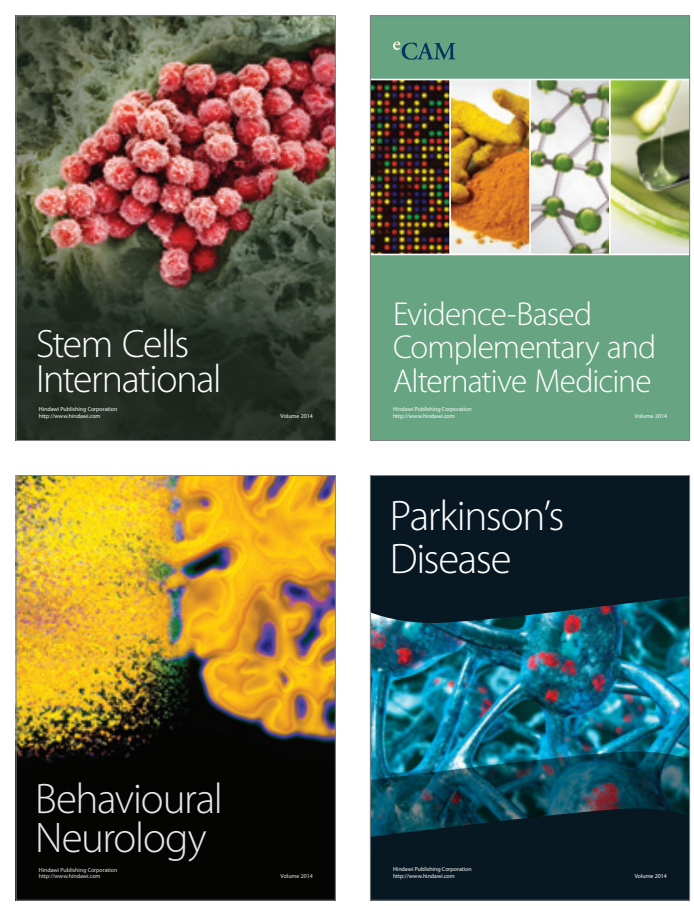

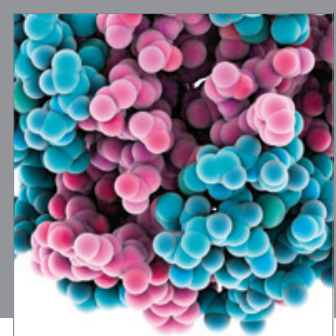

Journal of
Diabetes Research

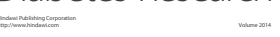

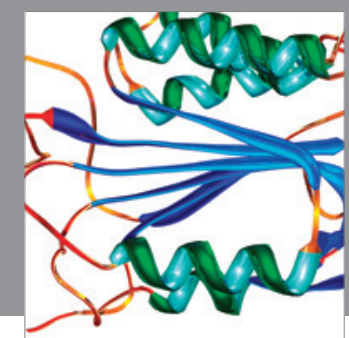

Disease Markers
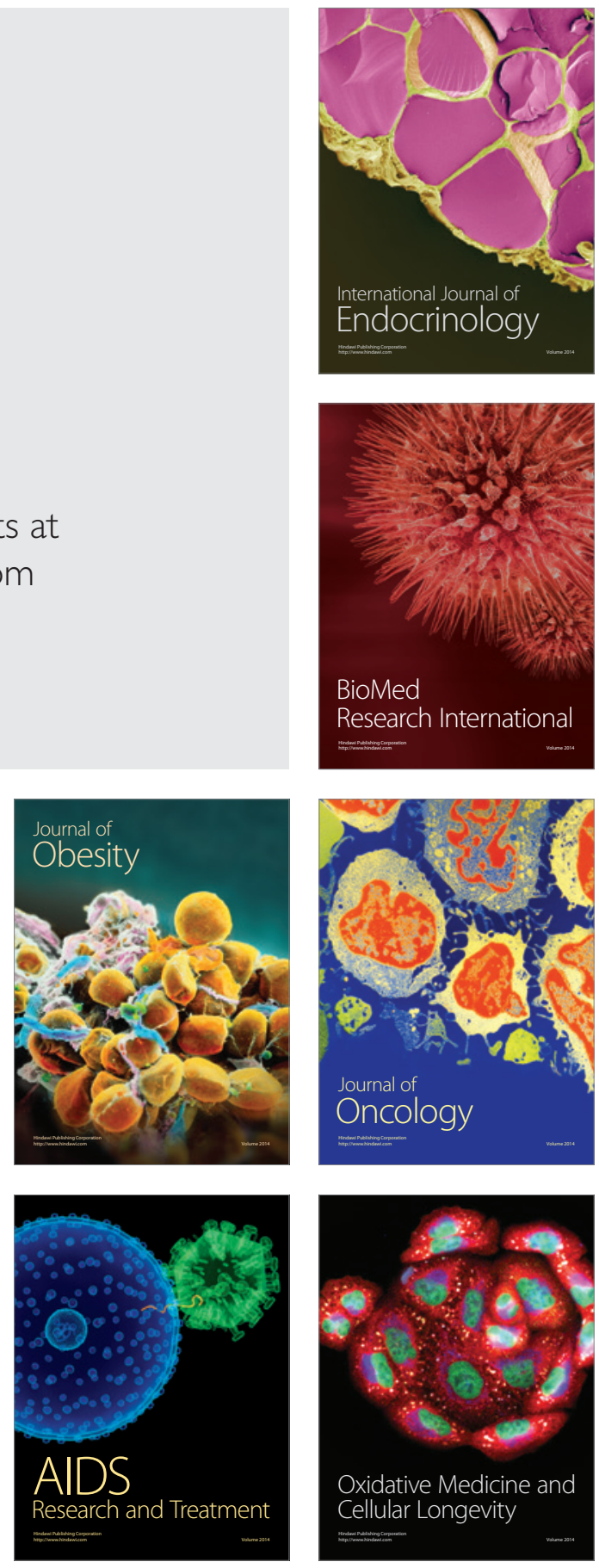